\title{
Literatür ve Sahanın Kesişiminde Dijital Göçmenler İçin Dijital Yetkinlikler*
}

\author{
Metin Eken (Dr. Öğr. Üyesi) \\ Erciyes Üniversitesi Illetişim Fakültesi \\ metineken@erciyes.edu.tr
}

Başvuru Tarihi: 10.07.2021

Yayına Kabul Tarihi: 27.07.2021

Yayınlanma Tarihi: 30.07.2021

https://doi.org/10.17680/erciyesiletisim.969495

\section{Öz}

Türkiye Ulusal Ajansı tarafından yürütülmekte olan Erasmus+ Programı Okul Eğitimi Stratejik Ortaklıklar eylemi kapsamında finanse edilen DigiComp kısa adıyla "Dijital Göçmenler için Dijital Yeterlilikleri Artırma: Dijital Bölünme ve Dijital Sosyal Eşitsizlikle Mücadele" projesi kapsamında hazırlanan bu çalışma, dijital göçmenler için dijital yetkinlikleri konu edinmektedir. Özellikle düşük ve orta eğitim düzeyindeki ve ileri yaşlardaki dijital göçmenlerin dijital bölünmeyle ilişkili ciddi risk faktörleriyle karşı karşıya oldukları gerçeğinden hareket eden çalışma, dijital teknolojilerin benimsenmesine ilişkin kapasite geliştirme çabalarına; dijital göçmenlerin sahip olması gereken dijital yetkinliklerin, literatür taraması ve uzman görüşleri çerçevesinde daha net bir resmini ortaya koyarak farklılıklara ve fikir birliğine dayalı bir yetkinlik çerçevesi geliştirmek yoluyla katkı sunma amacı taşımaktadır. Bu çerçevede dijital göçmenlerin dijital teknolojilerle ilgili hangi sorumluluk ve sorun alanlarıyla karşı karşıya oldukları ve bu alanlardaki yetkinliklerinin hangi kategorilerde ele alınabileceği literatür taraması marifetiyle ifade edilmiş; saha kısmında ise ilgili literatürden elde edilen veriler çerçevesinde 11 uzmanın görüşlerine başvurulmuştur. Son olarak da ilgili literatür ve sahanın kesişiminde elde edilen veriler bir yetkinlik çerçevesi olarak somutlaştırılmıştır.

Anahtar Kelimeler: Dijital Bölünme, Dijital Eşitsizlik, Dijital Göçmenler, DigiComp, Dijital Yetkinlikler.

\footnotetext{
* Bu çalışma, DigiComp kısa adı ve "Dijital Göçmenler için Dijital Yeterlilikleri Artırma: Dijital Bölünme ve Dijital Sosyal Eşitsizlikle Mücadele" başıı̆ıyla Türkiye Ulusal Ajansı tarafından yürütülmekte olan Erasmus+ Programı Okul Eğitimi Stratejik Ortaklıklar eylemi kapsamında desteklenmektedir.
} 


\title{
Digital Competencies for Digital Immigrants at the Intersection of Literature and the Field
}

\author{
Metin Eken (Asst. Prof. Dr.) \\ Erciyes University Faculty of Communication \\ metineken@erciyes.edu.tr
}

Date Received: 10.07 .2021

Date Accepted: 27.07.2021

Date Published: 30.07.2021

https://doi.org/10.17680/erciyesiletisim.969495

\begin{abstract}
This study focuses on digital competencies for digital immigrants and was prepared within the scope of the project entitled "Improving Digital Competencies for Digital Immigrants: Tackling with Digital Divide and Digital Social Inequality", abbreviated to DigiComp, which was funded as part of the Erasmus+ Program School Education Strategic Partnerships action carried out by the Turkish National Agency. Based on the fact that digital immigrants with only primary or secondary levels of education, particularly those of advanced age, face serious risk factors associated with the digital divide, the study focuses on capacity building efforts related to the adoption of digital technologies and aims to contribute to the development of a competency framework based on differences and consensus by presenting a clearer picture of the digital competencies that digital immigrants should have, within the framework of literature review and expert opinions. The literature review conducted in this study focuses on digital technologies and the areas of responsibility and issues faced by digital immigrants in their use as well as under which categories their competencies in these areas can be addressed. In terms of field, the opinions of 11 experts were consulted based on the data obtained from the relevant literature. Finally, the data obtained from the intersection of the relevant literature and the field were embodied in the form of a competency framework.
\end{abstract}

Keywords: Digital Divide, Digital Inequality, Digital Immigrants, DigiComp, Digital Competencies. 


\section{Giriş: Dijital Bölünme, Kuşak Farkı ve Dijital Göçmenler}

Dijital bölünme sosyal, ekonomik ve politik alanları kuşatan bir kamu politikası terimi olarak yeni bilgi teknolojilerine erişimi olanlarla olmayanları ayıran boşluğa referansla 1990'lı yılların ortalarında gündeme gelmiştir (Srinuan \& Bohlin, 2011). "Bilgisayar ve internet teknolojilerine eşitsiz erişim başta olmak üzere farkl nedenlerle bu teknolojilerin eşitsiz kullanımı ve bu kullanımından elde edilen avantajların farklılaşması sonucu oluşan ve çeşitlenen eşitsizliklere işaret eden dijital bölünme kavramı" sonraları çok yönlü araștırmaların konusu haline getirilmiştir (Özsoy, 2020, s. 11).

Erken tartışmalarda dijital medyaya fiziksel erişim, bölünmeyi ortadan kaldıracak temel bir unsur olarak ele alınırken zamanla erişimden ziyade dijital medyayı kullanabilmenin ve uygulama için gerekli becerilerin önemi ortaya çıkmıştır (van Dijk, 2016, s. 274). Nitekim bilgisayar ve internet teknolojilerine fiziksel erişim aynı zamanda mutlak olarak onları kullanmaya olanak sağlayacak becerileri beraberinde getirmemektedir. Aynı șekilde erişim olanaklarının önemli ölçüde genişlediği Batı Avrupa ülkeleri örnekliğinde dahi dijital bölünmenin ortaya çıkardığı sorunlar aşılamamıştır. Özellikle pandemi sürecinde daha çok ev içi ortamlarda zaman geçirmek zorunda kalan yaşlıların eğlenme, sosyalleşme, sağlık ve iyi oluş, mesleki faaliyetler gibi sayıları çoğaltılabilecek pek çok alanda yaşadıkları sorunlar, sahip olma ya da fiziksel erișimden ziyade beceri ve kullanım odaklı sorunlar olarak göze çarpmaktadır. Sosyal izolasyon sebebiyle kendilerine teknik konularda destek sunabilecek yakınlarından uzak kalmaları, beceri gelişiminin ve kullanımın önündeki önemli engellerden sadece birini örneklemektedir.

van Dijk ve van Deuersen, "dijital teknolojiye erişimin dört basamağı" şeklinde ifade ettikleri kurguda tam da bu soruna odaklanmaktadırlar. Onlara göre erişim, yeni teknolojinin tamamen benimsenmesi süreci olarak daha geniş bir perspektifte ele alınmalıdır ve bu çerçevede dört temel adımdan bahsedilebilir; motivasyon, fiziksel erişim, beceriler (operasyonel, formel, enformasyon, iletişim, içerik oluşturma ve stratejik beceriler) ve kullanım $(2014$, s. 2). Bu kurguda motivasyon yeni bir teknolojinin benimsenmesi sürecinin ilk aşaması olarak kritik bir öneme sahiptir. Hayata sonradan dahil olan bir teknik araca ilişkin kaygı ve teknolojinin olumsuz etkilerine yönelik popüler eleştirilerden kaynaklı sebeplerle gelișen ve kullanıma yönelik motivasyonu olumsuz yönde etkileyen koşullar nüfusun çeşitli kesimlerinde etkinliğini sürdürmektedir (van Dijk \& van Deursen, 2014, s. 3). Özellikle dijital göçmenlere yönelik beceri geliştirme çalışmalarına dair literatürde bu sorun sıklıkla ortaya konmaktadır (Sütlüoğlu, 2020). Söz konusu kurguda fiziksel erişim dijital medyaya, en temelde bilgisayar ve internete erişimi ifade ederken beceriler, sürecin kilit bileşeni olarak okuryazarlık ve yetkinlik kavramlarını da içeren işlevsel bir noktada konumlanmaktadır. Kullanım ise dijital teknolojiye erişimin nihai aşamasıdır. Bu noktada kullanım kalıpları, kullanım sıklı̆̆ı ve süresi, kullanım çeșitliliği ve türleri gibi unsurlar ön plana çlkar (van Dijk \& van Deursen, 2014, s. 3-4).

Tüm bu dört basamağın ve özellikle de becerilerin pek çok faktörle ilişkili olduğunu, yer yer onlardan etkilendiğini ve bu faktörlerle ilișkili araștırma girișimlerinin dijital bölünme literatürünü şekillendirdiğini ifade etmek mümkündür. Eğitim (Cruz-Jesus vd., 2016; Shirazi vd., 2010; Zhao vd., 2007), yaş (Akhter, 2003; Chaudhuri vd., 2005; Pieri \& Diamantinir, 2010; Prensky, 2001a), yetenekler ve deneyim (Brown \& Licker, 2003; Waycott vd., 2010; Wilbon, 2003), gelir ve sosyo-ekonomik durum (Chakraborty \& Bosman, 2002; Elena-Bucea vd., 2020; Noh \& Yoo, 2008), kültür (Hubregtse, 2005; Klimaszewski \& Nyce, 2009) ve sayıları çoğaltılabilecek pek çok faktör bu çerçevede tartışılmaktadır. 
Söz konusu faktörler arasında sıklıkla tartışma konusu haline getirilen ve bu çalışma açısından da merkeze alınan temel unsur yaştır. Pek çok araştırma girişimi yaş arttıkça, ilişkili diğer unsurların da etkisiyle motivasyon, erişim, beceri ve kullanım kategorilerinde önemli değişimlerin ortaya çıktığını göstermektedir. OECD verilerine göre (OECD, 2001); ilgili ülkelerde bilgisayar kabullenimi ve internet erişimi gençlerde yaşlılara oranla daha düşük seyretmektedir ve kullanım, genç yaş gruplarında daha hızlı büyüme eğilimindedir. En yüksek oranda kullanım 35-45 yaş grubunda gözlemlenmektedir. Vartanova ve Gladkova'nın (2019, s. 203) Poushter'den (2006, s. 11) alıntıladıkları bir tablo üzerinden yaptıkları çıkarımları da önde gelen Avrupa ülkelerinde benzer sonuçları işaretlemektedir. Buna göre farklı yaş grupları arasında internet kullanımına ilişkin boşluklar devam etmekte ve bu kuşak farkının açık bir sonucu, dijital yerliler olarak da adlandırılan genç insanlar tarafından mümkün olan en yüksek düzeyde internet kullanımıyla gösterilmektedir.

Kullanıma odaklanan bu araştırmaların yanı sıra ağ ortamlarını kullanma becerilerinde de belirgin kuşak farklılıklarının olduğu çeşitli araştırmalara yansımaktadır. Hargittai'nin (2020) 2001 yılında New Jersey'de rastgele örneklem yoluyla seçtiği farklı yaş, cinsiyet ve sosyo-ekonomik statü gruplarına yönelik olarak çevrim içi becerileri ölçme girişimleri, bu durumu aşağıdaki tabloya yansıdığı şekliyle ortaya koymaktadır.

Tablo 1. Başarıly Tamamlanan Görev Sayısı Ortalaması ve Yaşa Göre Görevlere Harcanan Zaman

\begin{tabular}{|l|c|c|c|c|c|}
\hline Yaş Aralıkları & $\begin{array}{c}\text { Başarılı Olarak } \\
\text { Tamamlanan } \\
\text { Görev Sayısı } \\
\text { Ortalaması }\end{array}$ & $\begin{array}{c}\text { Görevlerin } \\
\text { Standart Sapması }\end{array}$ & $\begin{array}{c}\text { Görevlerde } \\
\text { Harcanan } \\
\text { Ortalama } \\
\text { Süre (dk.) }\end{array}$ & $\begin{array}{c}\text { Zamanın Standart } \\
\text { Sapması }\end{array}$ & Gözlem Sayısı \\
\hline $10-19$ & 5 & 0.00 & 6.7 & 3.96 & 3 \\
\hline $20-29$ & 4.67 & 0.49 & 8.2 & 3.97 & 12 \\
\hline $30-39$ & 4.17 & 1.33 & 15.7 & 6.11 & 6 \\
\hline $40-49$ & 4.21 & 0.58 & 14.0 & 6.94 & 14 \\
\hline $50-59$ & 4.13 & 1.13 & 19.1 & 8.44 & 8 \\
\hline $60-69$ & 3.75 & 1.49 & 13.5 & 6.49 & 8 \\
\hline $70+$ & 3.33 & 1.15 & 24.4 & 7.50 & 3 \\
\hline
\end{tabular}

"Tablo on yıllara bölünmüş yaş gruplarının başarılı olarak tamamladıkları görevlerin ortalamasını göstermektedir. 18 ve 19 yașındakiler tüm görevlerde başarılıyken, 70 ve 80'lerinde bulunan bireyler ortalama 3.33 görevi, 60'larındaki bireyler de dörtten az görevi başarıyla tamamlamıştır. Tablo aynı zamanda on yıllara bölünmüş yaş gruplarının beş görev için harcadıkları ortalama süreyi de göstermektedir" (Hargittai, 2020).

Her ne kadar özellikle becerilere dönük istatistiki veriler sınırlı olsa da Türkiye bağlamında da özellikle kullanım pratikleri bakımından benzer bir görünümün olduğu ifade edilebilir. TÜİK'in Hanehalkı Bilişim Teknolojileri (BT) Kullanım Araştırması (2020) kapsamında son üç ay içinde bireylerin yaş grubuna ve cinsiyetine göre bilgisayar ve internet kullanım oranlarına bakıldığında en yüksek oranlarda internet kullanımı 16-24 yaş grubu $(\% 91,8)$, 25-34 yaş grubu $(\% 93,5)$ ve 35-44 yaş grubunda $(\% 89,1)$ gözlemlenmektedir. Yaş arttıkça kullanım oranlarında düşüş eğilimi olduğu görülmektedir. Buna göre internet kullanım oranları 45-54 yaş grubunda \%74,8, 55-64 yaş grubunda $\% 50,9$ ve $65-74$ yaş grubunda $\% 27,1$ 'dir.

Artan yaşla ilişkili önemli bir faktör olan eğitim düzeyi de eklendiğinde hem Türkiye'de hem de Avrupa'da sorunlu bir görünümün ortaya çıtığı ifade edilebilir. Avrupa ülkeleri 
ile karşılaştırmalı veriler sunan Eurostat'a (2019) göre Türkiye ve AB ülkelerinde internet kullanan bireylerin farklı eğitim düzeyleri ve yaş gruplarına göre dijital yetenek düzeyleri incelendiğinde, Türkiye'de düşük eğitim seviyesinde 25-64 yaş grubunun \%82'si, 5574 yaş grubunun \%93'ü, düşük seviye dijital yeteneklere sahiptir. AB'de ise aynı eğitim seviyesindeki 25-64 yaş grubunun \%60'ı, 55-74 yaş grubunun ise \%67'si, düşük seviye dijital yeteneklere sahiptir. Yine Türkiye'de orta eğitim düzeyindeki 25-64 yaş grubunun \%44'ü, 55-74 yaş grubunun \%73'ü, düşük seviye dijital yeteneklere sahiptir. AB'de ise yine aynı eğitim seviyesinde 25-64 yaş grubunun \%36'sı ve 55-74 yaş grubunun ise \%48'i, düșük seviyede dijital yeteneklere sahiptir.

Sunulan istatistiki verilerin akabinde dijital bölünmede yaş faktörüne ilişkin önemli bir hususa dikkat çekilmelidir. Dijital kültürün meydana getirdiği koşullara toplumun tüm kesimlerinin eşit oranda katılım ve adaptasyon sağladığını ifade etmek elbette mümkün değildir. Yaş olgusu da mevcut koşullarda tek başına bir anlam ifade etmemektedir. Yaş; biyolojik, psişik, ekonomik ve tekno-kültürel süreçlerin kesiştiği noktada önemli bir belirleyen olarak ortaya çıkmaktadır (Figan ve Dede Özdemir, 2020). Yeni iletişim araçlarıyla kurulan ilişkinin biçimini ve mesafesini belirleyen ve geniş bir yelpazeye yayılan bireysel ve toplumsal eşitsizlikler; erişime, kullanıma, becerilere ve yeni teknolojilere ilişkin algısal farklılıkları da beslemektedir. Dolayısıyla ilerleyen yaş ile birlikte, bireyin yașamını yoksullaştıran her türden unsurun, sorunun, dijital eșitsizlikleri de farklı boyutlardan beslediği/besleyeceği ayrıca not edilmelidir (Sütlüoğlu, 2020).

Bu noktada her iki grubu da homojen gruplar olarak kabul etmeden, kendi içindeki çeşitlilikleri ve kendine has farklılaşmaları göz önünde bulundurarak bir dijital yerli ve dijital göçmen ayrımından ve bu kategoride ele alabileceğimiz bir bölünmeden bahsedilebileceğini ifade etmek mümkün görünmektedir. İlk defa Prensky (2001a, 2001b) tarafından kavramsallaştırılan ve geniş bir etki uyandıran söz konusu ayrım, öğrenme alanlarımızı ve kendimizi yeniden șekillendiren hızlı teknolojik değișimleri haritalamanın ve anlamanın bir yolu olarak, evvela eğitim süreçlerinde ve daha geniş kültürel bağlamlarda çeşitli tartışmalar üretmiş̦tir. Yaygın ve popülerleşen araştırma girişimlerinde her iki grubun da homojen gruplarmış gibi resmedilmesi, göçmenlerin eskilik, modası geçmişlik ve analog dünyaya bağımlılık gibi negatif niteliklerle anılması gibi hususlar, ayrımın kaba bir dikotomik çerçeveye tekabül ettiğine yönelik eleştirilere de yol açmıştır (Bayne \& Ross, 2007).

Ancak bu çalışmanın kurgusunda da netlikle görüleceği üzere söz konusu ayrım, yaş ve onunla ilişkili çeşitli faktörleri göz önünde bulunduran demografik bir referans çerçevesi olarak kullanılmaktadır. Nitekim yaşla ilişkili bir biçimde eğitim düzeyi, cinsiyet, ekonomik imkânlar, fiziksel ve psikolojik iyi oluş, kültürel kaynaklar, sosyal sermaye gibi pek çok değişkenin süreç değerlendirmelerinin önemli bir parçası haline getirilmesi ciddi bir gereklilik ve önem arz etmektedir. Bu çalışmada da literatür taraması ve saha araştırması bu gereklilik ve önem çerçevesinde şekillendirilmiştir. Tüm bu veriler, özellikle düşük ve orta eğitim düzeyindeki dijital göçmenlerin dijital bölünmeyle ilişkili ciddi risk faktörleriyle karşı karşıya olduklarına işaret etmekte; bugün küresel ölçekte günlük hayatın neredeyse her boyutuna uzanan bir eylem alanına dönüşen dijital ortamların yetişkin eğitimine doğru genişleyen bir enformasyon ortamı içinde ele alınması zorunluluğunu açık bir biçimde göstermektedir. Çalışma bu sorunsaldan hareket ederek dijital teknolojilerin benimsenmesine ilişkin kapasite geliştirme çabalarının akademik zeminine katkı sunmanın yanında farklılıklara ve fikir birliğine dayalı bir yetkinlik çerçevesi 
geliştirme girişimini ortaya koyma amacı taşımaktadır. Bu genel amaç ve tasarım çerçevesinde aşağıdaki sorulara yanıtlar aranmıştır:

1. Dijital göçmenlerin karşı karşıya kaldıkları dijital teknolojilerle ilgili sorumluluk ve sorun alanları nelerdir?

2. Dijital göçmenlerin karşı karşıya kaldıkları dijital teknolojilerle ilgili sorumluluk ve sorun alanlarına yönelik yetkinlik kategorileri nelerdir?

3. Dijital göçmenler, karşı karşıya kaldıkları dijital teknolojilerle ilgili sorumluluk ve sorun alanlarına yönelik yetkinlik kategorilerinde hangi yetkinliklere sahip olmalıdırlar?

$\mathrm{Bu}$ soruların ilk ikisi özelde literatür taraması yoluyla somutlaştırılması amaçlanan sorulardır. Uzman görüşlerine dayalı saha araștırması ise hem ilk iki sorunun tahkim edilmesi hem de üçüncü soruya ilişkin genel bir çerçevenin ortaya konulması amacı taşımaktadır. Çalışma günümüzde, bilgi ve iletişim teknolojilerinin benimsenmesine ilişkin politika geliştirme süreçlerinin artan ölçüde merkezi gündemlerinden biri haline gelen dijital bölünmenin dezavantajlı mensuplarından oluşan dijital göçmenlere odaklanması bakımından önem arz etmekte, tasarımı ve çıktıları bakımından literatürdeki ilgili çalışmalardan farklılaşmaktadır.

\section{Araştırma Tasarımı}

Araştırma, çalışmanın amaçsal karakteri çerçevesinde iki boyutlu bir tasarım arz etmektedir. İlk boyut literatür taramasına ilişsindir ve en temelde yaş ve ilişkili pek çok faktörün dahil olduğu dijital bölünmeden kaynaklı sorun ve sorumlulukların hangi alanlarda karşımıza çıktığını ve bu alanlarda somutlaştırılacak yetkinlik kategorilerini ortaya koyma amacı taşımaktadır. Çalışmanın ikinci boyutu ise nitel bir karakter arz etmektedir. Söz konusu tasarımla dijital göçmenlerin dijital teknolojilerle ilgili sorumluluk ve sorun alanlarına yönelik yetkinlik kategorilerinde hangi yetkinliklere sahip olmaları gerektiği uzman görüşleri çerçevesinde ele alınacaktır. Nitel boyut, ele alınan konuya ilişkin literatürün uzman bakış açısıyla tahkim edilmesine yöneliktir. Bu yolla araştırma problemiyle ilgili derinlemesine bir keşif faaliyetinin yanında ele alınan sosyal gerçekliğin çeşitli yönleriyle anlaşılması hedeflenmektedir.

\subsection{Araştırma Grubu}

Araştırmanın nitel boyutunda çalışma grubunun belirlemesi sürecinde, amaçlı örnekleme yöntemlerinden "ölçüt örnekleme yöntemi" kullanılmıştır. Ölçüt örnekleme, örneklemin problemle ilgili olarak belirlenen niteliklere sahip kişiler, olaylar, nesneler ya da durumlardan oluşturulmasıdır (Büyüköztürk, 2012). Bu çerçevede Türkiye'de konuyla ilgili on bir uzmanın görüşlerine başvurulmuştur. Uzmanların belirlenmesi sürecinde ölçüt olarak uzmanların, dijitalleşme ve dijital kültür alanlarıyla ilişkili akademik çalışmalar yapmış olmaları göz önünde bulundurulmuştur. Nitekim belirlenen uzmanların hem literatüre ilişkin yetkinlikleriyle ve hem de dijital göçmenlere ilişkin odak gözlem ve araştırmalarıyla ilgili araştırma amaçlarının gerçekleşmesi açısından kilit öneme sahip oldukları ifade edilmelidir.

Tablo 2. Katılımcıların Uzmanlık Alanı ve Mensubu Oldukları Kuruluşlara Göre Dağılımı

\begin{tabular}{|l|l|l|}
\hline & Katılımcı Uzmanlık Alanı & Katılımc Kuruluşu \\
\hline U1 & İletişim, Dijital Kültür, Dijital Bölünme & Erciyes Üniversitesi \\
\hline U2 & İletişim, Dijitalleşme, Dijital Kültür & Erciyes Üniversitesi \\
\hline U3 & İletişim, Dijital Kültür, İletişim Sosyolojisi & Erciyes Üniversitesi \\
\hline
\end{tabular}




\begin{tabular}{|l|l|l|}
\hline & Katılımcı Uzmanlık Alanı & Katılımcı Kuruluşu \\
\hline U4 & Eğitim, Eğitim Teknolojisi, Dijitalleşme & Erciyes Üniversitesi \\
\hline U5 & İletişim, Dijitalleşme, Dijital Kültür & Erciyes Üniversitesi \\
\hline U6 & Sosyoloji, Dijitalleşme, Dijital Kültür & Erciyes Üniversitesi \\
\hline U7 & İletişim, Dijitalleşme, Dijital Kültür & Selçuk Üniversitesi \\
\hline U8 & İletişim, Dijitalleşme, Dijital Kültür & Akdeniz Üniversitesi \\
\hline U9 & İletişim, Dijitalleşme, Dijital Kültür & Anadolu Üniversitesi \\
\hline U10 & İletişim, Dijitalleşme, Dijital Kültür & Sakarya Üniversitesi \\
\hline U11 & İletişim, Dijitalleşme, Dijital Kültür & İstanbul Üniversitesi \\
\hline
\end{tabular}

\subsection{Veri Toplama Süreci}

Araştırmanın literatür taramasına ayrılan ilk boyutunda; Google Scholar, ScienceDirect, PubMed, SpringerLink, ULAKBİM Keşif gibi veri tabanları aracılı̆̆ıyla ilgili anahtar kelimeler taratılmış ve çıkan sonuçlar çalışmanın amaçsal karakteri çerçevesinde tasnif edilmiştir. Araştırmanın nitel boyutundaki veri toplama sürecinde ise "yarı yapılandırılmış uzman görüşme tekniği" kullanılmıştır. Görüșme öncesinde, belirlenen uzmanlara "dijital yeterliliklere sahip bir dijital göçmen o kişidir ki ." şeklinde bir yönlendirmede bulunulmuş ve kendilerine sunulan yönerge çerçevesinde bu bilgi isteğine maddeler halinde cevap vermeleri istenmiştir. İlgili yönergede, çalışmanın amaçları doğrultusunda ve farklı hedef gruplara odaklanan yetkinlik çerçeveleri örnekliğinde kendilerinden beklenen katkının çerçevesi çizilmiştir.

\subsection{Veri Analizi}

Araştırma katılımcılarına sunulan yönerge, görüşme verilerinin analiz edilmesi sürecinde tematik alanların oluşturulmasına kaynaklık etmiştir. Yönergede katılımcılara DigComp 2.1 Avrupa Komisyonu Vatandaşlar için Avrupa Dijital Yeterlilik Çerçevesi'nde sunulan beş temel yetkinlik kategorisinde; ancak Türkiye'deki dijital göçmenler özelinde görüşlerini ifade etmeleri talep edilmiştir. Görüşme verileri bu kategoriler (bilgi ve veri okuryazarlığı, iletişim ve işbirliği, dijital içerik oluşturma, güvenlik, problem çözme) ile literatürden elde edilen bilgiler çerçevesinde ve Cresswell'in $(2018$, s. 183) veri analiz sarmalında (verileri düzenleme, okuma ve hatırlatıcı notlar alma, sınıflama, yorumlama) ortaya koyduğu usulle analiz edilmiştir.

\subsection{Etik Kurul İzni}

$\mathrm{Bu}$ çalışma, Erciyes Üniversitesi Sosyal ve Beşeri Bilimler Etik Kurulu tarafından, 29/06/2021 tarihli ve 284 başvuru numaralı onay formu ile etik açıdan uygun bulunmuştur.

\section{Bulgular ve Yorum}

\section{1. İlgili Literatür Çerçevesinde Dijital Göçmenlerin Karşı Karşıya Kaldıkları Dijital Teknolojilerle İlgili Sorumluluk ve Sorun Alanları}

Çalışmanın giriş kısmında ana hatlarıyla ifade edilen yaş ve ilişkili pek çok faktörün dahil olduğu dijital bölünmeden kaynaklı sorun ve sorumlulukların hangi alanlarda karşımıza çıktığı, beceri/yetkinlik çerçevesi geliştirme girişimlerinin cevap vermesi gereken temel soruların başında gelmektedir. Dijital göçmenlerin karşı karşıya kaldıkları dijital teknolojilerle ilişkili sorumluluk ve sorun alanlarını tartışmak bu alanlarda hangi yetkinliklere ihtiyaç duyulduğunu öncelemesi açısından da önem arz etmektedir. $\mathrm{Bu}$ bakımdan ebeveynlik, meslek, sağlık ve iyi oluş, dijital vatandaşlık, hayat boyu öğrenme, iletişim-etkileşim ve eğlenme-sosyalleşme gibi alanlar, konuya ilişkin geniş literatür 
incelendiğinde özellikle dijital göçmenler için ele alınması gereken sorumluluk ve sorun alanlarını işaretlemektedir. Bu tasnif tüm sorun ve sorumluluk alanlarını kuşatma iddiasından ziyade bazı ana hatlara ilișkin çerçeve sunma amacı taşımaktadır. Yine her biri müstakil bir çalışma kapsamında değerlendirilebilecek bu hususlar çalışma sınırlılıkları çerçevesinde, firsatlar ve riskler temelinde, genel açıklamalar ve sınırlı örnekler üzerinden ele alınacaktır.

\subsubsection{Ebeveynlik}

Günümüz çocukları, hem fiziksel hem de bilişsel, duygusal ve sosyal gelişimlerine doğrudan etki etme potansiyeline sahip dijital araçların etkinliğindeki bir dijital kültür içerisine doğmaktadırlar. Fırsatlar ve risklerle örülü bu karmaşık dünya, ebeveynler için de benzer bir görünüm arz etmekte; ancak aynı zamanda ebeveynlik rolleri açısından yeni sorumluluklar ortaya çıkartmaktadır. Livingstone ve Bryne çocuklarla olumlu ve istikrarlı bir duygusal bağ kurma, davranış kontrolü, çocuğun bireyselliğine saygı duyarak sağlıklı bir benlik gelişimini destekleme, uygun davranış modelleri oluşturma, ihtiyaç ve beklentilerini karşılayarak onları koruma gibi temel ebeveynlik rollerinin çocukların dijital dünyası da dahil olmak üzere tüm durumlara ve ortamlara kolayca uygulanabilir olduğunu söyler (2018, s. 21). Ancak buradaki asıl sorun, bu rollerin dijital çağda nasıl ve ne ölçüde yerine getirilebileceğidir.

$\mathrm{Bu}$ çerçevede Yurdakul ve arkadaşları dijital ebeveynliğe dair bir tanım girişiminde bulunmuş ve bu tanımdan yola çıkarak bir rol sınıflandırmasına gitmişlerdir. Buna göre dijital ebeveyn "dijital çağın gereksinimlerine göre hareket eden, temel düzeyde dijital araçlara hâkim, uçsuz bucaksız dijital ortamlardaki olanakların farkında olan ve çocuğunu bu ortamlardaki risklere karşı koruyabilen, kişi haklarına gerçek hayatta saygı duyulması gerektiği gibi sanal ortamda da aynı şekilde davranılması gerektiğini çocuğuna aşılayan ve teknolojik gelişmelere kendini kapatmayan bireydir." Bu tanımdan hareketle ifade edilen roller ise dijital okuryazarlık, farkında olma, kontrol, etik ve yenilikçiliktir (2013). İlk madde dışındaki tüm maddeler esasında dijital ebeveynliğin gerektirdiği dijital okuryazarlık becerileriyle ilişkili olarak ele alınabilir. Yine buradaki en temel sorun da söz konusu rollerin nasıl ve ne ölçüde yerine getirilebileceğidir.

Nitekim tüm dünyada çocukların internete erişimlerinin arttığı, ebeveyn denetimi zor olan mobil cihazların her geçen gün ebeveynlerin anlamakta zorlanacakları karmaşık kullanım alanlarını içerdiği ölçüde onlar da kendilerini zor durumda hissetmektedirler. Ayrıca ebeveynler ekran süresinin artması, internet bağımlılığı ve yabancılardan kaynaklı tehlikelerle ilgili popüler endișelerden de etkilenmektedirler. Bu nedenle normatif olarak ebeveynlerden beklentiler artsa da yapabileceklerinin pratik sinırlarının olduğu göz önünde bulundurulmalıdır (Livingstone \& Byrne, 2018, s. 20). Hele ki yaşla ilgili kısıtlayıcı faktörler sebebiyle dijital bölünmenin dezavantajlı paydaşları arasında sayılabilecek bazı dijital göçmenler açısından değerlendirildiğinde durum daha da kritik bir hal almaktadır.

Ebeveynler arasında dijital teknolojilerin kullanımının yaygınlaştığı bilinen bir gerçektir. Bunun çocuklara bakan yönlerinden bir tanesi de henüz adım dahi atmadan önce çocukların ebeveyn paylaşımları aracılığıyla dijital ayak izlerine sahip olmalarıdır. Gün geçtikçe artış gösteren çocuk merkezli ebeveyn paylaşımları, parenting/ebeveynlik ve share/paylașım kelimelerinden türetilmiş 'sharenting' kavramının literatüre dahil olmasına sebebiyet vermiştir. İlgili literatür bilinçsizce yapılan paylaşımların, çocukları yaşamları boyunca takip edecek zararlar ortaya çıkarabileceğini, ebeveynlerin farkında dahi olmadan çocuklarının mahremiyet ve unutulma haklarını ihlal edebileceklerini ve 
onların başkaları tarafından istismar edilmelerine aracı olabileceklerini ifade etmektedir (Çimke vd., 2018; Blum-Ross \& Livingstone, 2017; Chalklen \& Anderson, 2017; Kumar \& Schoenebeck, 2015).

Ayrıca çocukların ebeveynlerinin medya kullanımını etkileyen aktif ajanlar olduğu ve onların dijital araçları kullanımlarına önemli etkilerde bulunduklarına dair literatür göz önünde bulundurulduğunda (Ambert, 2001; Nelissen \& Van den Bulck, 2018) bu durumun ebeveyn-çocuk etkileşimini nasıl şekillendireceği ve ebeveynlik rolleri açısından ne gibi sonuçlar üreteceği dijital göçmenler açısından konuya ilişkin önemli bir parametre olarak değerlendirilmelidir.

\subsubsection{Meslek}

Dijital göçmenlerin mesleki yaşamlarına ilişkin önemle üzerinde durulması gereken hususlardan ilki, dijitalleşmeyle ilişkili gereksinimler çerçevesinde mevcut mesleki yaşamın sürdürülmesidir. Özellikle ilerlemiş yaş gruplarında ve düşük eğitim düzeyine sahip bireyler için riskli bir görünümün ortaya çıktığı istatistiki verilere de yansımaktadır. OECD Yetişkin Becerileri Anketi'nden (PIAAC) elde edilen sonuçlar, OECD genelinde yaşlı işçilerin teknolojik ilerleme ve küreselleşmenin getirdiği beceri gereksinimlerindeki değişikliklerle başa çıkmak için yeterince donanımlı olmadıklarını göstermektedir. İlgili verilere göre pek çok OECD ülkesi genç nesillerin matematik, okuryazarlık ve bilgi ve iletişim teknolojileri (BİT) becerilerini artırma konusunda önemli ilerlemeler kaydetmiş olsa da bu becerilerin ortalama düzeyi genellikle daha büyük yaş grupları için düşük kalmaktadır. Ortalama olarak 55-65 yaşındakilerin üçte birinin bilgisayar deneyimine sahip olmadığı veya temel BİT testlerinde başarı elde edemediği görülmektedir (OECD, 2019).

Dijital göçmenlerin algısı da sunulan istatistiki verilerle benzerlik arz etmektedir. Dijital göçmenlerin çalışma yaşamlarına ilişkin algılarına odaklanan bir saha araştırması, söz konusu bireylerin (51-76 yaş arası) yaşları sebebiyle ayrımcılığa maruz kaldıklarını ve iş yaşamlarını sürdürmeye dönük teknolojik beceriler bakımından yetersizlik hissettiklerini ortaya koymaktadır. Ancak araştırmaya yansıyan bir diğer önemli husus, katılımcıların dijital yeterliliklerini arttırmaya odaklanan eğitimlere katılmak noktasında istekli olmalarıdır (Lee vd., 2009). Bu durum dijital yetkinlikleri geliştirmeye dönük çabaların başarı oranlarını artırma potansiyeli içermesi bakımından önemlidir.

Özellikle Covid-19 pandemisi sürecinde ortaya çıkan bir diğer önemli husus ise uzaktan çalışma koşullarına adaptasyonla ilgilidir. Krizin dijitalleşmeyi bireyin güvenliğinin ve yaşamının korunması temelinde vazgeçilmez bir unsur olarak ön plana çıkartmasıyla birlikte (Eken, 2021) uzaktan mesleki yaşamın gerektirdiği dijital okuryazarlık becerileri, hem firsatların yakalanması hem de risklerden korunma temelinde önemli bir gereksinim olarak belirmiştir. Avrupa Parlamentosunun uzaktan çalışmanın çalışanlar ve toplum üzerindeki etkisine dair raporuna göre COVID-19 salgını sırasında ev tabanlı tele-çalışmanın artan kullanımı, AB ülkelerindeki nüfus grupları arasında önceden var olan dijital bölünmeleri ağırlaştırmıştır. Raporda yaşa ilişkin önemli bir veri, düşük dijital yeterliliklere sahip yaşlıların önemli bir kısmının işten çıkarılmayla sonuçlanan yaptırımlarla karşı karşıya gelmeleridir (Samek Lodovici vd., 2021). Tüm bu veriler dijital göçmenlerin mesleki yaşamlarına yönelik dijital beceri geliştirme çabalarının gerekliliğini gözler önüne sermektedir. 


\subsubsection{Sağlık ve İyi Oluş}

Dijital bölünmenin yaş ve ilişkili diğer faktörler çerçevesinde yansıma bulduğu çeşitli riskler ve firsatlarla örülü alanlardan bir diğeri de sağlık ve iyi oluştur. Bu noktada "sağlık okuryazarlığı" hem risklerin azaltılması hem de firsatlardan yararlanılması bakımından önemli bir parametredir. Kavram "insanların bilinçli seçimler yapmak, sağlık risklerini azaltmak ve yaşam kalitesini artırmak için sağlıkla ilgili bilgileri arama, anlama, değerlendirme ve kullanma için geliştirdikleri geniş beceri ve yeterlilikler yelpazesi" olarak ifade edilebilir (Zarcadoolas vd., 2005). İstatistiki veriler ilerleyen yașın önemli risk faktörlerinden biri olduğunu ortaya koymaktadır. Avrupa Sağlık Okuryazarlığı Araştırması, araştırmaya dâhil edilen sekiz Avrupa ülkesindeki yetişkinlerin neredeyse yarısının, sağlıklarını olumsuz şekilde etkileyecek düzeyde yetersiz veya sorunlu sağlık okuryazarlığı becerilerine sahip olduğunu göstermiştir (The HLS-EU Consortium, 2012). Türkiye Sağlık Okuryazarlığı Düzeyi ve İlişkili Faktörleri Araştırmasına göre de sağlık okuryazarlığı yetersiz olanların sıklığının 18-24 yaş grubundaki en düşük değerden (\% $14,0)$, ilerleyen yaş grupları ile birlikte artarak 65 ve üzeri yaş grubunda \%65,5’e kadar yükseldiği görülmektedir. 65 ve üzeri yaş grubunda $\% 24,9^{\prime} l u k$ sorunlu-sınırlı sağlık okuryazarlığı düzeyi ile birlikte değerlendirildiğinde, bu yaş grubundakilerin \%90,4'ünün sağlık okuryazarlığının kısıtlı olduğu görülmektedir (Özkan vd., 2018).

Dijital göçmenlerde ilerleyen yaşla birlikte düşen sağlık okuryazarlığının önemli parametrelerinden biri sınırlı dijital becerilerdir. Sağlık bilgisi arama, edinme süreçleri, konuya ilişkin riskleri ve firsatları açıkça gözler önüne seren bir örnek olması bakımından önemlidir. İnternet, günümüzde her yaștan insanın sağlık bilgisini arama edinme süreçlerinde en sık başvurduğu kaynaklardan biridir. Bu noktada teknolojiye fiziksel erişimden ziyade kullanım becerilerine yönelik eksiklikler sorunlu görünümler ortaya çıkartabilmektedir. Bu konuda karşılaşılan risklerden biri sağlığa ilişkin çevrim içi enformasyonun denetimsiz dolaşımının oluşturduğu yanlış bilgilenme ve sağlıkla ilgili bilgiler konusunda bir karmaşa ve kaygının ortaya çıkmasıdır. Maftei ve Holman'ın (2020) da çerçevelediği üzere özellikle Covid-19 pandemisi sürecinde yaygınlaşan ve tam da bu durumu ifade eden siberkondri, yaş ve eğitim düzeyiyle de ilişkili ciddi bir sorun haline gelmiştir.

Söz konusu risklerin yanında bilgisayar becerilerindeki gelişimin yaşlı yetişkinlerin daha bağımsız bir yaşam sürmelerine ve sağlık sorunları hakkındaki bilgilerini artırmalarına izin vererek güçlendirmeye de hizmet edebileceği çeşitli çalışmalara yansımaktadır (Karavidas vd., 2005). Bu aynı zamanda giderek yaşlanan nüfusun sağlık ihtiyaçlarını karşılama potansiyeline sahip çok çeşitli uygulamaları ve müdahaleleri kapsayan dijital sağlık teknolojileri için de geçerlidir. Güven ve motivasyondaki artışla birlikte artan beceriler, söz konusu teknolojilerin benimsenmesi ve faydalı kullanımı açısından kritik bir rol oynamaktadır (Curtis \& Price, 2017).

\subsubsection{Dijital Vatandaşılık}

Dijital bölünmenin yansıma bulduğu alanlardan biri de diğer alanları da belli ölçülerde içerebilen dijital vatandaşlıktır. Motivasyon ve kullanım becerilerinin önemli ölçüde etkilediği geniş bir yetkinlikler kapasitesini gerekli kılması sebebiyle dijital bölünmeye etki eden faktörler tarafından da olumsuz etkilenmesi beklenen alanların başında gelmektedir. Literatürde dijital vatandaşlığın pek çok tanımına rastlanmakta ve bu tanımların çok geniş bir alana işaret ettiği görülmektedir. Örneğin Mossberger ve arkadaşları (2008, s. 2) dijital vatandaşlı̆̆ topluma çevrim içi katılma yeteneği olarak ifade ederken dijital 
vatandaşları, interneti günlük yaşamlarında düzenli ve etkili bir şekilde kullananlar olarak tanımlamaktadır. Yine Avrupa Konseyi de (2021) dijital vatandaşlığın; dijital teknolojiler ve verilerle (yaratma, yayınlama, çalışma, paylaşma, sosyalleşme, araştırma, oynama, iletişim kurma ve öğrenme) yetkin ve olumlu etkileşimi ifade ettiğine yönelik bir kavramsal çerçeve geliştirmiş ve "her düzeyde (politik, ekonomik, sosyal, kültürel ve kültürlerarası) topluluklara (yerel, ulusal, küresel) aktif ve sorumlu bir şekilde (değerler, beceriler, tutumlar, bilgi ve eleștirel anlayıș) katılmak; yaşam boyu öğrenme (resmi, gayri resmi, yaygın ortamlarda) ve insan onurunu ve ilgili tüm insan haklarını sürekli olarak savunmaktan oluşan ikili bir sürece dâhil olmak" șeklinde bir tanım geliștirmiștir.

Dijital vatandaşlığın dijital okuryazarlık becerilerini kapsayan bu geniş tanımları, onu çalıșma kapsamında belirli boyutlar üzerinden sınırlandırmayı gerekli kılar. Choi'nin (2016) dijital vatandaşlığı oluşturan 4 ana kategorisi bu çerçevede yol gösterici olması bakımından önemlidir. Bunlar; etik, medya ve bilgi okuryazarlığı, katılım/etkileşim ve eleştirel dirençtir. Bu çerçevede çalışma kapsamında dijital vatandaşlık kavramı daha çok etik ve katılım boyutlarıyla ele alınmaktadır. Söz konusu tasnifte etik, üç alt temada somutlaştırılmıștır. Bunlardan ilki dijital teknolojilerin güvenli, sorumlu ve etik kullanımının bilinmesiyle ilgilidir. Diğer tema ise dijital vatandaşların gündelik yaşamlarında dijital teknolojilerin yaygın kullanımından kaynaklanan/kaynaklanacak politik, sosyal, kültürel, ekonomik ve eğitimsel konuların farkında olmalarıyla ilgili olan dijital farkındalıktır. Son olarak da dijital haklar ve sorumluluklar temasında, dijital ortamlara ilişkin hakların bilinmesine (ifade özgürlüğü hakkı, gizlilik hakkı, fikri mülkiyet, telif hakkı koruması ve siber zorbaları ve zararları bildirmek de dahil olmak üzere, kendilerine, başkalarına ve topluma saygı duymak) vurgu yapılmıștır (Aldemir \& Avşar, 2020; Choi, 2016). Katılım kategorisi de politik, ekonomik ve kültürel katılım ile kişiselleştirilmiş katılım temalarını içermektedir. Bu çalışma kapsamında özellikle e-devlet benzeri uygulamaların kullanılması gibi katılım süreçleri, dijital vatandaşlık kategorisinin önemli beceri bileşenlerinden biri olarak kabul edilmektedir. Nitekim COVID-19 pandemisi de kamu hizmetlerinin artan dijitalleşmesi ve pek çok kurumun tekno-sosyal bir karakter arz etmesi sebebiyle dijital göçmenler için katılım süreçlerine yönelik beceri gelişimini kritik bir noktaya taşımaktadır.

\subsubsection{Hayat Boyu Öğrenme}

Bilgi ve enformasyon teknolojilerine erişimin yaygınlaştığı ülkelerde dijital teknolojilerin gündelik hayata artan entegrasyonuna paralel bir biçimde nüfusun da giderek yaşlanması, söz konusu teknolojilerin dijital göçmenler için kaçınılmaz bir noktada konumlandığını göstermektedir. Türkiye örneğinde de özellikle pandemi döneminde dijital göçmenler dijital teknolojileri, sosyal izolasyondan görece kurtulmak, kamu hizmetlerinden faydalanmak ve benzeri faaliyetler için artan oranda kullanmaya başlamıştır. Söz konusu teknolojilerin dijital göçmenler için bir fırsatlar alanı olarak konumlandırdığı bir diğer yaygınlaşan faaliyet alanı ise hayat boyu öğrenmedir. "Hayat boyu öğrenme, kişisel, sivil, sosyal veya istihdamla ilgili perspektifler dahilinde bilgi, beceri ve yeterlilikleri geliştirmek amacıyla yaşam boyunca üstlenilen tüm öğrenme faaliyetlerini kapsar (https://ec.europa.eu/, t.y.)."

$\mathrm{Bu}$ çerçevede özellikle e-öğrenme kanallarıyla hayat boyu öğrenme, öğrenmede belirli bir derecede esneklik sağlayarak yetişkinlerin zaman ve mekan açısından karşılaştıkları engelleri aşma olanakları sunmakta, uzak coğrafi bölgelerde bulunan ve öğrenme konusunda günlük kısıtlamalarla karşı karşıya kalan yetişkinlere yeni öğrenme firsatları getirerek erişimi artırmaya yardımcı olmaktadır (OECD, 2003). Ayrıca hayat boyu 
öğrenme yetişkinler için, fiziksel, bilişsel ve sosyal olarak sağlıklı bir yaşam tarzının önemli bir bileşeni olarak konumlanmaktadır. Araștırmalar, sürekli öğrenmenin yaşlı yetişkinler için bilişsel işlev, sağlık ve esenlik, sivil katılım, sosyal içerme ve özgüven açısından önemli faydalar sağladığını göstermektedir (von Doetinchem \& Livingston, 2021). Ancak dijital bölünme, hayat boyu öğrenme için de önemli risk faktörlerinden biri olarak konumlanmaktadır. Artan yaş ve ona eşlik eden gelir, eğitim düzeyi, engellilik gibi sayıları arttırılabilecek pek çok faktör hem motivasyona hem de beceriye dayalı bölünmeleri tetiklemekte; hayat boyu öğrenmeye dönük pratik ve somut faydaların kazanımı engelleyebilmektedir.

\subsection{6. İletişim-Etkileşim ve Eğlenme-Sosyalleşme}

İlerleyen yaş, tüm dünyada sosyal izolasyon riskini artıran önemli bir faktör olarak görülmektedir (Gao vd., 2021; Yang \& Victor, 2011). Dijital göçmenlerin ileri yaş düzeyindeki tüm mensupları için sosyal izolasyon, COVID-19 pandemisi gibi olağanüstü koşullarda da sıklıkla gündeme gelen bir konu olmuştur. Bu çerçevede teknoloji, pek çok çalışmada yaşlı yetişkinlerin karşılaştığı sosyal katılım zorluklarının üstesinden gelmeye yardımcı olabilecek, sanal ve ortak faaliyetler yoluyla sosyal içermeyi kolaylaştırabilecek bir unsur olarak ele alınmıştır (Amundsen, 2021; Baecker vd., 2014; Baez vd., 2019).

Dijital göçmenlerin ileri yaşlardaki mensuplarına yönelik araştırmalarda bilgi ve iletişim teknolojilerinin iletişim-etkileşim amaçlı kullanımına dair önemli sonuçların ortaya çıktığl görülmektedir. Buna göre dijital teknolojilerin 60 yaş üstü bireyler tarafından benimsenmesine yönelik bir araștırma, söz konu yaş grubundaki bireylerin internet hakkında en faydalı buldukları șeyin aile ve arkadaşlarla iletişim olduğunu ortaya koymaktadır (Kirby vd., 2017). Yine yaşlı yetişkinlerin teknoloji kullanımına dair görüşlerine başvurulan bir diğer araştırmada katılımcılar, teknolojinin iletişimde esnekliği arttırmasına özellikle dikkat çekmişlerdir (Chopik, 2016). Bu olumlu algı kullanıma da yansımakta, çeşitli yaş gruplarından dijital göçmenlerin interneti sıklıkla iletişim ve etkileşim amaçlı kullandıkları görülmektedir (Gorard vd., 2003). Bu çerçevede bazı motive edici sebeplerin olduğu da ifade edilebilir. Örneğin özellikle ileri yaş grubunda, çocukların ailelerden ayrılmasıyla birlikte çocuklar ve torunlarla iletişim kurarak sosyalleşmenin, yaşlıları bilgi ve iletişim teknolojilerinin kullanımı hakkında daha fazla bilgi edinmeye sevk ettiği ifade edilmelidir (Ivan \& Fernández-Ardèvol, 2017). Tüm bu veriler dijital göçmenlerin özellikle ilerleyen yaș, engel, coğrafi kısıtlama gibi sebeplerle dezavantajlı konumdaki mensupları için teknolojiyle aracılanmış iletişim ve etkileşimin kritik önemini gözler önüne sermektedir.

Sosyal katılımın, artan yaşla birlikte insanların sağlığına ve esenliğine büyük faydalar sağladığı bilinmektedir. Başkalarıyla temas halinde olmaktan grup faaliyetlerine katılmaya kadar, sosyal olarak aktif kalmanın, yaşa bağlı düşüşlerin etkilerini yavaşlatmaya, yalnızlık ve sosyal izolasyon risklerini ve hatta yaşlılıkta ölüm riskini azaltmaya yardımcı olabileceği ilgili araştırmaların sıklıkla ortaya koyduğu bir husustur (Baez vd., 2019). Bu noktada teknoloji, dijital göçmenlerin sosyalleşmesi bakımından kritik bir konumdadır ve ilgili literatür daha düşük depresyon ve yalnızlık, artan yaşam doyumu ve daha yüksek sosyal destek imkanlarıyla teknolojinin eğlenme ve sosyalleşme süreçlerindeki rolüne işaret etmektedir (Cotten vd., 2014; Zhang \& Kaufman, 2015).

Dijital araçlar yoluyla eğlenme de yaşlı yetişkinler için sosyal izolasyonu azaltmanın etkili araçlarından biridir (Chen, 2020). Örnek olması bakımından dijital oyunların yaşlı kullanıcılar için faydalarına yönelik bir araştırma, dijital oyunları oynamanın önemli 
bir terapötik değeri olduğunu ortaya koymaktadır. Ayrıca çalışmada dijital oyunların, diğer kullanıcılar gibi yaşlı insanların da hem çevrim içi hem de fiziksel olarak aynı yerde bulunan diğerleriyle sosyal olarak bağ kurmasına olanak tanıdığı ve potansiyel olarak sosyal destek yapılarını genişlettiği ifade edilmektedir (Ijsselsteijn vd., 2007). Ancak ne yazık ki çalışma kapsamında vurgulanan yaşa bağlı dijital bölünme, bu alanı da hem firsatları hem de riskleri değerlendirmenin zorlaşabildiği bir sorun alanı haline getirmektedir.

\subsection{Sorumluluk ve Sorun Alanlarına Yönelik Yetkinlik Kategorileri}

Dijital teknolojilerle etkileşimin ortaya çıkardığı yeni sorumluluk ve sorun alanları, bu alanlara yönelik, beceri, yeterlilik ve yetkinliklerin gelişimine odaklanan pek çok kavramın ortaya çıkmasına zemin hazırlamıştır. Süreç içerisinde internet okuryazarlığı, dijital okuryazarlık, bilgisayar okuryazarlığı, ağ okuryazarlığı, enformasyon okuryazarlığı gibi muhtelif kavramsallaştırmalar ortaya çıkmış ve bu çeşitlilik yelpazesi her geçen gün genişlemiştir.

Söz konusu kavramsal girişimler yanında bilgi, beceri ve tutumu da içeren yetkinlik/ competence kavramı ön plana çıkmakta ve dijital yetkinlik kavramı, alana ilişkin politika belirleme çabalarının merkezinde yer almaktadır (Ala-Mutka, 2011). Bu çerçevede Avrupa parlamentosunun hayat boyu öğrenme için sekiz temel yeterlilikten biri olarak kabul ettiği "dijital yetkinlik" konuya ilişkin kapsamlı bir çerçeve sunması bakımından bu çalışmada da tercih edilmiştir. Dijital yetkinlik kategorilerinin belirlenmesinde de Avrupa Komisyonunun dijital yeterlilikler için ortaya koyduğu çerçeve metni olarak kabul edilen DigComp kısa adıyla Vatandaşlar için Avrupa Dijital Yeterlilik Çerçevesi (versiyon 2.1) referans alınmıştır (Carretero vd., 2017).

Tablo 3. DigComp 2.1 Temel Yetkinlik Kategorileri (Carretero vd., 2017)

\begin{tabular}{|c|c|c|c|c|}
\hline $\begin{array}{l}\text { 1. Bilgi ve Veri } \\
\text { Okuryazarlığı }\end{array}$ & 2. İletişim ve İşbirliği & $\begin{array}{l}\text { 3. Dijital İçerik } \\
\text { Oluşturma }\end{array}$ & 4. Güvenlik & 5. Problem Çözme \\
\hline $\begin{array}{l}1.1 \text { Verileri, bilgileri } \\
\text { ve dijital içeriği } \\
\text { tarama, arama, } \\
\text { filtreleme } \\
1.2 \text { Veri, bilgi ve } \\
\text { dijital içeriğin } \\
\text { değerlendirilmesi } \\
1.3 \text { Verileri, } \\
\text { bilgileri ve dijital } \\
\text { içeriği yönetme }\end{array}$ & $\begin{array}{l}\text { 2.1 Dijital teknolojiler } \\
\text { aracılığıyla etkileşim } \\
2.2 \text { Dijital teknolojiler } \\
\text { aracılığıyla paylaşım } \\
\text { 2.3 Dijital teknolojiler } \\
\text { aracılığıyla } \\
\text { vatandaşlığa } \\
\text { dahil olmak } \\
\text { 2.4 Dijital teknolojiler } \\
\text { aracılığıyla işbirliği } \\
\text { 2.5 Netiket } \\
\text { 2.6 Dijital kimliği } \\
\text { yönetme }\end{array}$ & $\begin{array}{l}\text { 3.1 Dijital içerik } \\
\text { geliştirme } \\
\text { 3.2 Dijital içeriğin } \\
\text { entegre edilmesi } \\
\text { ve yeniden } \\
\text { detaylandırıması } \\
\text { 3.3 Telif hakkı } \\
\text { ve lisanslar } \\
\text { 3.4 Programlama }\end{array}$ & $\begin{array}{l}\text { 4.1 Cihazların } \\
\text { korunması } \\
4.2 \text { Kişisel verilerin } \\
\text { ve gizliliğin } \\
\text { korunması } \\
4.3 \text { Sağlığın ve } \\
\text { esenliğin korunması } \\
4.4 \text { Çevrenin } \\
\text { korunması }\end{array}$ & $\begin{array}{l}\text { 5.1 Teknik } \\
\text { sorunları çözme } \\
5.2 \text { İhtiyaçların ve } \\
\text { teknolojik yanıtların } \\
\text { belirlenmesi } \\
5.3 \text { Dijital } \\
\text { teknolojileri } \\
\text { yaratıcı bir şekilde } \\
\text { kullanmak } \\
5.4 \text { Dijital yeterlilik } \\
\text { boşluklarını } \\
\text { belirleme }\end{array}$ \\
\hline
\end{tabular}

DigComp 2.1 aynı zamanda her bir yeterlilik kategorisi için sekiz yeterlilik seviyesi tanımlamıştır. Her bir seviye o noktada kazanılması gereken bilgi, beceri ve tutuma ilişkindir ve ayrıca vatandaşların bilişsel zorluklarına, üstesinden gelebilecekleri görevlerin karmaşıklığına ve görevi tamamlamadaki özerkliklerine göre yetkinliği edinmelerinde bir adımı temsil eder (Carretero vd., 2017). Bu çerçevede çalışmanın amaçsal tasarımı kapsamında söz konusu seviyelerin ilk dört adımını kapsayan "temeller/ foundations" ve "intermediate/orta düzey", dijital göçmenlere yönelik kurgunun hedeflenen yeterlilik düzeylerini ortaya koymaktadır. 


\subsection{Sahanın Sesi: Dijital Göçmenler İçin Dijital Yetkinlikler}

Sahadan elde edilen bulgular; bilgi ve veri okuryazarlığı, iletişim ve işbirliği, dijital içerik oluşturma, güvenlik, problem çözme şeklinde beş temel kategori çerçevesinde sunulacaktır.

\subsubsection{Bilgi ve Veri Okuryazarlığı}

Bilgi ve veri okuryazarlığı; veri, bilgi ve dijital içeriğin aranması, değerlendirilmesi ve yönetilmesi süreçleriyle ilişkili temel yeterliliklerdendir. Dijital göçmenler için özellikle sağlık, alışveriş, haber, inanç/maneviyat gibi pek çok alana yönelik önemli bir yetkinlik çerçevesi olarak somutlaşmaktadır. Bu çerçevede uzmanların dikkat çektiği ilk konu arama motorlarının kullanımına yöneliktir ve dijital yeterliliklere sahip bir dijital göçmen;

Arama motorlarını kullanarak merak ettiği haber, olay ya da konu hakkında bilgiye erişebilir. U1

Arama motorlarını etkin ve sağlıklı kullanabilir. U2

Arama motorlarını istekleri ve ihtiyaçları doğrultusunda kullanabilir. U3

Arama motorlarında sözcük ve sözcük grubu bazında arama yapabilir. Çıkan sonuçlar arasında tercih yaparak web sitelerine girip ilgili içeriğe ulaşabilir. U4

Merak ettiği bir konuyu telefonlarındaki arama motorlarını kullanarak araștırabilir. U6

Veri, bilgi ve dijital içeriğin aranması süreçlerinde arama motorlarının kullanılması gerektiğine yönelik vurgu aynı zamanda arama motorlarının nasıl kullanılması gerektiğine yönelik önerilerle desteklenmektedir:

Arama motorlarının bilgiyi belli ölçütlere göre sıraladığı konusunda bilgi sahibidir ve önüne çıkan sıralamanın her zaman en doğru bilgiye değil en popüler olana göre sıralandığını bilir. U8

Bir görselin veya bilgi parçasının kaynağına ulaşma konusunda bilgi sahibidir. Örneğin Google görsellerde arama yapabilmelidir. U8

Arama motorlarının sunduğu içeriklerin reklam ve çok tıklanma oranlarına göre ön sıralarda çıktığını bilerek gerekli elemeleri yapabilir. U6

Bunun yanında erişilen verilere eleştirel bir perspektiften yaklaşılması gerektiğine ve içeriğin teyit edilmesi gerektiğine yönelik vurgu da dikkat çekmektedir;

Aramalarıyla ilgili emin olamadığı durumlarda ne gibi bilgi doğrulama yöntemleri olduğunun farkındadır. Paylaşılan tüm içeriklere eleștirel yaklaşma kabiliyeti kazanmıştır. U2

Dijital göçmen internet üzerinde karşılaștığı tüm içeriğin doğru olduğuna inanmamalı ve bu bilginin geçerlik ve güvenirliğini test edebilmelidir. U4

Dijital göçmenlerle ilgili temel sorun bilgiye ve içeriğe ulaşmaktan çok ulaşllan enformasyonun ne düzeyde ayıklanabildiği, kullanıcı açısından kullanışlı hale getirilebildiği, yani içeriğin değerlendirilmesi ve yönetilebilmesidir. Hemen heryaştan kullanıcı açısından ciddi bir problem olan bu hususta da dijital yerlilere kıyasla dijital göçmenler daha dezavantajlı bir konumdadır. Dijital yerliler, çok daha iyi tanıdıkları ve hızlı şekilde kullandıkları dijital ortamlar ve akıllı telefonlar aracılığıyla ulaștıkları içeriği gerekirse yine bașka dijital ortamlardan faydalanarak daha kolay şekilde teyit edebilmekteyken, dijital göçmenler genelde karşılarına çıkan ilk birkaç sitedeki enformasyonu doğru kabul etmeye daha meyilli olmaktadırlar. U6

Doğrulama platformları hakkında bilgi sahibidir. U8

Eriştiği her bilginin gerçekliğine ve doğruluğuna eleştirel bir gözle bakıp sorgulayabilme becerisine sahiptir. İhtiyaç duyulan bilgiyi doğru dijital kaynaklardan arayabilir, kaynaklar arasında karşılaștırma yaparak eriștiği içeriği teyit edebilir. U11

Görüşmeciler ayrıca çalıșma kapsamındaki literatür taraması sonucunda tasnif edilen, dijital göçmenlerin karşı karşıya kaldıkları sorumluluk ve sorun alanlarının bir kısmına 
da dikkat çekmişlerdir. Bu çerçevede sağlık ve iyi oluş ile dijital vatandaşlığın ön plana çıktığı görülmektedir.

E-devlet üzerinden sunulan bilgilere ulaşabilir; sunulan hizmetlerden yararlanabilir. E-nabız üzerinden sunulan bilgilere ulaşabilir; sunulan hizmetlerden yararlanabilir. Merkezi Hekim Randevu Sistemi (MHRS) üzerinden randevu alabilir. Hayat Eve Sığar uygulamasını kullanabilir. Dijital bankacılık sitelerini ve uygulamalarını kullanabilir. Resmî kurumların (valilik, belediyeler, bakanlıklar vb.) sosyal medya hesaplarını takip ederek, bu hesapların sunduğu enformasyona (duyuru, bilgilendirme, basın açıklaması vb.) ulaşabilir. Alışveriş sitelerinden ve uygulamalarından alışveriş yapabilir, sipariş verebilir. U5

Resmi kurumların hesaplarından sunulan bilgilere ulaşabilir. U1

Sağlık ve alışverişle ilgili aramalarını gerçekleștirebilir. Edindiği bilgilerin doğruluğuna eleştirel yaklaşarak davranış düzeyinde doğru kararı verir. U6

Sağlık bilgisini doğru dijital kaynaklardan arayabilir, kaynaklar arasında karşılaştırma yaparak eriştiği içeriği teyit edebilir.

\subsection{2. İletişim ve İşbirliği}

Dijital teknolojiler aracılığıyla iletişim; etkileşim, paylaşım, işbirliği, vatandaşlığa dahil olma, nezaket ile dijital kimliği yönetme gibi süreçlerle ilişkilidir. Bunlardan ilki olan "etkileşime" yönelik beceri merkezli pratik yeterliliklere görüşmecilerin birçoğu tarafından vurgu yapılmıştır. Bu çerçevede dijital yeterliliklere sahip bir dijital göçmen;

Cep telefonunun rehberine yeni bir numara kaydedebilir. Cep telefonunun rehberinde arama yapabilir. WhatsApp, BİP gibi anlık mesajlaşma uygulamalarını kullanabilir. Anlık mesajlaşma uygulamaları "son görülme" ve "mavi tik" gibi işaretçilerin ne anlama geldiğini bilir. Anlık mesajlaşma uygulamaları ile fotoğraf, video ve ses kaydı gönderebilir. Kendisine gönderilen fotoğraf, video ve ses kayıtlarını izleyebilir/dinleyebilir. U1

İletişim ihtiyaçlarını karşılamak adına telefon, sms, e-posta ve sosyal medya teknolojilerinden faydalanabilir. U4

Cep telefonunun rehberine yeni bir numara kaydedebilir; mevcut numaraları güncelleyebilir ya da silebilir. Cep telefonunun rehberinde arama yapabilir. Cep telefonundan kısa mesaj gönderebilir, gelen mesajları okuyabilir. WhatsApp, BïP gibi anlık mesajlaşma uygulamalarını kullanabilir. Kendisine gönderilen fotoğraf, video ve ses kayıtlarını izleyebilir/dinleyebilir. U5 Anlık mesajlaşma platformlarını kullanabilir. Mail gönderebilir, dosya yükleyebilir, gönderilen dosyaları açabilir. U8

İletişim ve etkileşime yönelik beceri merkezli pratik yeterliliklerle birlikte sosyal medya aracılığıyla "paylaşım"da bulunabilme ve "sosyalleşme" de görüşmecilerin vurgu yaptığı temaların başında gelmektedir;

Dijital göçmenler diğer insanlarla iletişim düzeyini artırmak ve sosyalleşmek adına iletişim teknolojilerini kullanabilmelidirler. U4

Bilhassa emekliliğe ayrılmış ya da daha sakin bir hayat yaşamaya başlamış, yaşlı kuşağa dahil edilebilecek yaş aralığına yaklaşan kimi yetişkinler, etraflarında söz söyleyebilecekleri kişiler ya da bu imkanı sağlayacak ortamlar bulamadıklarında bir yalnızlık psikolojisine girebilmektedirler. Dijital ortamlarda paylaşım yapma, başkalarıyla etkileşime geçme, kendi ilgisini çeken konularla ilgili son gelişmeleri takip etme veya hobileriyle ilgili bazı videoları izleyebilme gibi yeterliliklere sahip olan dijital göçmenler için bu mecralar, kullanıcıların kendilerini ifade edebilmeye ve diğer kullanıclarla irtibat kurma gibi temel insani tatminlerin yerine getirebilecekleri alanlara dönüşebilme potansiyeli taşımaktadır. U6

İnternetin, kişilerin bir araya gelmelerine, katılımcllı göstermelerine imkân sağlayan bir iletişim ağı olduğunu bilir. Bağlantısını kaybettiği arkadaşlarını sosyal ağlardan, mezun oldukları okulların topluluk sayfalarından arayıp bulabileceğini bilir. U8

Dijital yeterliliklere sahip bir göçmen o kişidir ki dijital ortamı çevreyle etkileşim halinde olmak, kişiler ve gruplar arası ilişkilerini sürdürmek için aktif olarak kullanabilir. U11 
Bu başlık altında en yoğun vurgu yapılan hususların başında, literatürde de önemli bir konum atfedilen ve dijital göçmenlerin yaşamlarını sürdürmelerinde kritik bir öneme sahip olan dijital vatandaşlık gelmektedir;

Kimseden yardım talep etmeksizin ihtiyaç duyduğu mobil uygulamayı uygulama marketlerinde bulur, cihazına indirir, uygulamayı kullanırlar. Bu e-devlet uygulaması olabileceği gibi banka uygulaması, yemek sipariș uygulaması ya da sosyal ağ uygulaması olabilir. Uygulama fark etmeksizin kullanabilirler. İndirdiği uygulamada ücret alınıp alınmadığının, hangi verilerinin kullanıldığının, giren önüne çıkanların reklam olabileceğinin farkındadırlar. U2

Vergi veya trafik gibi çeșitli borcu gibi çeşitli durumlara ait beyan, bilgi edinme ve ödeme yöntemlerini bilirler. Belediye olan borcunu e-devlet uygulamaları (G2C ve ticaretle uğraşanlar için G2B modelli uygulamalar) üzerinden nasıl ödeyebileceğini bilirler, uygularlar. U2

Devlet kurumları ve hizmet sektöründeki kurumların sayfalarından bir başkasının desteğine ihtiyaç duymadan yararlanabilirler. U3

Dijital dünyada bütün hizmetler artık dijital olarak yürütülmektedir. Bu kapsamda e-devlet, e-vatandaş gibi servislerin kullanılması dijital göçmenlerin yaşamını kolaylaştıracaktır. U4

Modern dönemde toplumsal hayatın ve kent kurgusunun bir gereği olarak yerine getirilmesi gereken bazı vazife ve pratiklerin dijital ortamlar aracılığılla gerçekleştirilebilmesiyle ilgili bir yeterliliktir. Sözgelimi fatura yatırmak, alışveriş yapmak, birisine para göndermek, kurumsal uygulamalar aracılığılla resmi işleri yapmak gibi gündelik hayatta belli düzeyde zahmet gerektiren işler, aslında çok kompleks bir bilgi gerektirmeyen bazı pratikler eşliğinde dijital ortamlar üzerinden kolaylıkla gerçekleştirilebilmektedir. Dijital göçmenlerin bu yeterliliklere en azından ortalama düzeyinde sahip olması, hayatlarındaki bazı zorluklarını aşmada onlara kolaylık sağlayacaktır. U6

"Dijital kimliği yönetmek" ve "nezaket" de görüşmecilerin vurgu yaptığı temel unsurlardır. Çalışma kapsamında ele alınan nezaket, uluslararası literatürde "network" ve "etiquette" kavramlarının bir araya gelmesiyle oluşturulan "netiquette" kavramıyla karşılanmakta, dijital mecralardaki nezaket ve görgü kurallarına karşılık gelmektedir (Scheuermann \& Taylor, 1997). Aynı zamanda dijital kimliğin yönetilmesiyle de doğru orantılıdır;

Sosyal ağlara üye olup nasıl profil oluşturacağını bilir ve akranlarıyla çevrimiçi iletişime geçebilir. Facebook, Instagram, YouTube, Spotify ve hatta Tinder gibi bir uygulamanın ne işe yaradı̆̆ını, nasıl üye olup orada nasıl bir profil oluşturacağını, o mecrada kimlerin olabileceğini ve sosyal ağlara nasıl dahil olunabileceğini bilir. U2

Anlık mesajlaşma uygulamalarında ve sosyal medya hesaplarının profillerinde gerekli gördüğü kadar kişisel bilgisini paylaşabilir. Profillerinin kimler tarafından görüntülenebileceğini kontrol edebilir. U5

Dijital yeterliliklere sahip bir dijital göçmen, internet ve sosyal medya ortamlarının gerektirdiği belli görgü kurallarının farkında olarak buna uygun bir kullanım pratiği geliştirebilir. Dijital ortamlarda akla gelen hemen her şeyin yazılamayacağına, her türlü görsel içeriğin paylaşılamayacağına, diğer kullanıcılarla uygun olmayan hitap șekillerle etkileșime geçilemeyeceğine dair bu mecraların yazılı ya da yazılı olmayan bazı etik ilkelerinin bulunduğuyla alakalı bir yeterliliktir. U6

Dijital yeterliliklere sahip bir dijital göçmen, dijital kimliğin hangi özellikler taşıdığını bilir ve bu kimliğini yönetebilir. Dijital teknolojilerin teknik özelliklerinden ve temel motivasyonlarından belli düzeyde haberdar olmak ve dijital kimliği bu farkındalıkla yönetebilmeye dair bir yeterliliktir. U6

Sanal mecralarda kendisi için oluşturduğu alanları bilinçli bir şekilde yönetir, koordine eder ve koruması yapar. U7

İnternet ortamında başkalarını yaralayabilecek içerik ve dil kullanmamaya dikkat eder. U8

Tüm bunların yanında görüşmecilerin iletişim ve etkileşim teması altında dijital göçmenlerin karşı karşıya kaldıkları sorumluluk ve sorun alanlarının bir kısmına da 
dikkat çektikleri ifade edilmelidir. Sağlık (U1), eğitim-hayat boyu öğrenme (U2) ve meslek (U2-U10) ön plana çıkan alanlar arasında yer almaktadır.

\subsubsection{Dijital İçerik Oluşturma}

Dijital içerik oluşturma, çeşitli amaçlarla dijital içeriğin geliştirilmesi, entegre edilmesi, düzenlenip yeniden organizasyonu, telif ve lisanslama, programlama gibi süreçleri kapsar. Ancak görüşmeciler, hedef kitleye yönelik olarak beceri ve farkındalık düzeyindeki basit ve pratik içerik geliştirme yeterliliklerini ön plana çıkartmışlar, içeriğin düzenlenmesi, yeniden organize edilmesi, telif ve lisanslama ile programlama gibi ileri düzey becerilere sınırlı düzeyde değinmişlerdir;

(Beceri) Cep telefonunu kamerası ile fotoğraf çekebilir. Cep telefonu kamerası ile video kaydedebilir. Not tutma uygulamaları ile yazdığı metinleri saklayabilir. U1

Cep telefonunu kamerası ile fotoğraf çekebilir; çektiği fotoğrafları telefonunda arşivleyebilir. Cep telefonu kamerası ile video kaydedebilir; kaydettiği videoları telefonunda arşivleyebilir. Not tutma uygulamaları ile yazdığı metinleri kaydedebilir. U5

(Farkındalık) Twitter'da veya YouTube'da ne gibi içerikleri nasıl oluşturabileceğini bilir. Gerekli teknik donanım ve teknik bilginin farkındadır. Buna ilaveten içerik oluştururken hukuki mevzuata nasıl uygun davranacağını, telif haklarını, uygulama kullanım şartlarını ve o uygulamanın ticari ve mali boyutunu bilir. U2

(Beceri) Fotoğraf, video, ses kaydı ve metin üretebilmelidir. Online platformların işleyişlerini ve yapılarını öğrenerek bu alanlara bilgive donanımı doğrultusunda içeriküretebilmelidir. Örneğin Wikipedia'ya katkıda bulunabilir. Fotoğrafçılık merakı olanlar, gezmeyi ve yemek yapmayı sevenler bloglar bu deneyimlerini kaydedip bloglarda veya diğer paylaşım platformlarında başkalarıyla paylaşabilmelidir. Sosyal platformlarda içeriklere yorum yapabilmeli, beğenisin veya hoşnutsuzluğu ifade edebilmelidir. U8

İçeriklerin düzenlenmesine ve yeniden organizasyonuna yönelik beceri ve farkındalık temelli görüşler ise bir uzman tarafından geniş bir biçimde dile getirilmiş; bu temeldeki yetkinlikler, aktif katılımcı olma, sosyalleșme ve esenlikle ilișkilendirmiștir;

\footnotetext{
Dijital yeterliliklere sahip bir dijital göçmen, internet ve sosyal medya ortamlarındaki içeriklerde düzenlemeler yapabilir ve gerek duyduğunda bunları geliştirebilir. Dijital ortamlarda metin, ses ya da görsel olarak çeşitlenen içeriklerde düzenlemeler yapılabileceğini ve bunların geliştirilerek hedef kitleye daha etkili şekilde hitap edebilecek içeriklerin ortaya çıarılabileceğini imleyen bir yeterliliktir. Yeni medyanın konvansiyonel medya ortamlarından farklılaşan en önemli özelliği, bilindiği üzere içeriğe müdahale edebilmeye veya içeriği yeniden düzenleyebilmeye izin vermesidir. Bu imkân, kullanıcıları yeni medya ortamlarında pasif bir alımlayıcı olmaktan kurtarır. Yeni medyanın günümüzdeki en popüler yüzü olan dijital ortamların bu avantajını fazlasıyla kullanan dijital yerlilerin aksine dijital göçmenlerin bu konuda geride oldukları açıktır. Web siteleri ve/veya sosyal medya platformları üzerinde yapılacak küçük çaplı siber-etnografik gözlemler dahi -hangi konu ve bağlamda ya da içerik türünde olursa olsun- dijital içeriklerin büyük ölçüde dijital yerliler tarafından oluşturulduğunu ortaya çıkaracaktır. Bu sonuç bana kalırsa yalnızca dijital yerlilerin dijital ortamlarda daha fazla yer almalarından kaynaklanmamakta, aynı zamanda dijital göçmenlerin bu konudaki eksikliklerini de açığa çıkarmaktadır. Belli bir disiplin içerisinde belli bir mantaliteyle kendileri tarafından oluşturulmuş içerikleri görmek, onların dijital ortamlardaki etkileşimlerini artıracak, böylelikle özsayglları ve özgüvenleri gelişecektir. U6
}

Yine U6, telif hakkı, lisanslar ya da programlama gibi unsurların daha üst düzeyde bir bilinçle birlikte hem bilişsel hem pratik beceri gerektiren yeterliliklere sahip olmayı gerektirdiğini ve bunun da dijital göçmenler için görece daha zor erişilebilecek bir düzey olduğunu ifade etmiştir. 


\subsubsection{Güvenlik}

Güvenlik; cihazların, kişisel sağlığın, kişisel verilerin ve mahremiyetin korunmasına ilişkin anahtar yetkinlik alanlarından biridir. Ayrıca dijital göçmenlerin beceri eksikliği sebebiyle ciddi risklerle karşı karşıya olduğu bir alana işaret etmektedir. Görüşmeciler bu alanda da hem becerilerin hem de uygun tutumların oluşumuna kaynaklık edebilecek bilgi ve farkındalık düzeylerinde anahtar yeterliliklere işaret etmişlerdir. Beceriler ve farkındalığa ilişkin örnek ifadeler aşağıdaki çerçevede somutlaşmaktadır;

(Beceri) Sosyal medya hesaplarının güvenliği için kullandığı parolanın öneminin farkındadır ve güçlü bir parola kullanır. U1

(Beceri) E-devlet, e-nabız, dijital bankacıllk, e-posta, sosyal medya gibi uygulama ve platformlarda kendine ait verilerin güvenliği için kullandığı parolanın öneminin farkındadır. Yaptığı paylaşımların kimler tarafından görüntülenebileceğini kontrol edebilir. Akıllı cep telefonunun gizlilik ayarlarını yapabilir. Konum hizmetlerini devre dışı bırakabilir. U2

(Beceri) İnternet halen dinamik bir alandır ve gerek yasal olarak gerekse internet șirketleri kendi iç işleyişlerini güncellemeye ve yeniden düzenlemeye devam etmektedir. Yapılan son düzenlemeleri ve güvenlik bildirimlerini takip etmelidir ve ona göre hareket etmelidir. U8

(Farkındalık) İnternet üzerinde verilerin kalıcllğının bilincindedir ve ona göre davranır. Sosyal ağlarda yaptığı paylaşımların çevrim dışı ortamdaki itibarını etkileyeceğinin bilincindedir. U1

(Farkındalık) Kişisel verilerinin dijital algoritmalar için ne denli önemli olduğunun farkındadır. Sosyal ağlar başta olmak üzere tüm dijital ortamlarda bilgi veya içerik paylaşırken kişisel verilerinin ne şekilde ve hangi amaçlarla kullanılacağını bilmesi gerektiğinin farkındadır. U2

(Farkındalık) Profilinde paylaştığı bilgilerin sosyal ağ siteleri tarafından reklam ve kişiselleștirme amacıyla kullanılacağının bilincindedir. İnternet üzerinde verilerin kalıcllı̆ının bilincindedir ve ona göre davranır. Sosyal ağlarda yaptığı paylaşımların çevrim içi ve çevrim dışı ortamdaki itibarını etkileyeceğinin bilincindedir ve ona göre davranır. U5

Güvenliğe yönelik farkındalık, çalışma sınırları bakımından her ne kadar birkaç örnek ifade üzerinden anlatılsa da görüşmeciler çok çeşitli riskleri göz önünde bulunduran ifadeler kullanmışlardır. Dolandırıcılık, kimlik hırsızlığı, yemlenme/oltalanma, hacklenme ve veri kaybı gibi riskler ön plana çıkan başlıklardır.

"Cihaz koruma”, "kişisel verilerin korunması" ile "sağlık ve esenliğin korunması" da görüşmecilerin vurgu yaptığı temel yeterliliklerin başında gelmektedir;

Dijital göçmenler ellerinde bulunan teknolojik araç ve gereçlerin bakımı ve korunmasını da üstlenmelidir. Örneğin cep telefonu veya bilgisayarların bozulmasına sebebiyet verecek kullanım biçimlerinden haberdar olmalı ve bunlardan uzak duracak şekilde beceriler geliştirebilmelidir. U4

Dijital göçmenler KVKK kapsamında bireysel hak ve sorumluluklarının neler olduğu hakkında bilgi sahibi olmalıdır. U4

Dijital yeterliliklere sahip bir dijital göçmen, dijital teknolojilerin bedensel veya psikolojik yönden bazı rahatsızlıklara sebebiyet verebileceği ihtimalini göz ardı etmez. Gündelik hayatın vazgeçilmez aracı haline gelen yeni teknolojilerin ve bilhassa da akıllı telefonların gerek yaymış olduğu radyasyona maruz bıraktığı gerekse kulak başta olmak üzere çeşitli organlara zarar verdiği bilinmektedir. Mobil halde sürekli olarak bu cihazlarla iletişim kurmak, insanı söz konusu rahatsızlıklara daha yakın kılmaktadır. Dijital ortamların büyülü dünyasına kapılmak, diğer taraftan bireyi psikolojik açıdan bazı rahatsızlıklara da götürebilmektedir. Așırı fotoğraf ve selfie çekmekle tetiklenen kendine hayranlık duygusu, çok sayıda takipçi edinmek suretiyle oluşabilecek fenomenlik duygusu veya yüksek sosyoekonomik statüye mensup kişilerin hesaplarını incelemek suretiyle kendi hayatıyla alakalı olarak yaşayacağız özgüvensizlik veya yalnızlık duygusu, sayıları arttırılabilecek pek çok örnekten bazıları olarak zikredilebilir. Dijital göçmenlerin her iki türdeki problemlerin farkına varması ve bunlarla alakalı kullanım pratikleri geliştirmesi, söz konusu yeterliliğin edinilmesiyle mümkün olacaktır. U6 


\title{
3.3.5. Problem Çözme
}

Problem çözme, teknik sorunların çözülmesi, dijital teknolojilerin ihtiyaçlara dönük ve kreatif kullanımı ve dijital yeterlilik boşluklarının belirlenmesiyle ilgilidir. Bu noktada en yoğun vurgu teknik sorunların pratik çözümüne yöneliktir.

\begin{abstract}
Akıllı cep telefonunun dokunmatik ekranı tepki vermediğinde cihaz üzerindeki fiziksel tuşları kullanarak cihazı yeniden başlatabilir. Akıllı cep telefonunda açık olan uygulamaları görebilir ve istediği zaman açık uygulamaları kapatabilir. Akıllı cep telefonuna kurduğu uygulamaların erişim izinlerini ayarlayabilir. Akıllı cep telefonunun ya da bilgisayarının internete bağlanmasını sağlayabilir. Akıllı cep telefonunun mobil internet bağlantısını kapatıp açabilir. Akıllı cep telefonunu ya da benzeri cihazlarını sessiz moda alabilir. U1-U5

Telefonun kilitlenmesi, herhangi bir programın kullanmaya izin vermemesi, bazı programlara girişlerin kullanıcı adı-şifre-parmak izi gibi bazı ilave tuşlamalarla mümkün olması ya da sosyal medya ortamlarında sözgelimi bir paylaşımın yanlışlıkla yapılması gibi karşılaşılan problemlerin üstesinden gelme noktasında dijital göçmenler büyük problemler yaşamaktadır. $\mathrm{Bu}$ yeterliliğin sağlanması, söz konusu problemleri aşma adına önemli kolaylıklar sağlayacaktır. U6

Cihazların işletim sistemleri hakkında genel bilgilere sahip olmalıdırlar. Yaşadıkları sorunun cihazdan mı, internet bağlantısından mı yoksa uygulamalardan mı kaynaklandığının ayırdına varabilmelidirler. U8
\end{abstract}

Dijital teknolojilerin ihtiyaca dönük kreatif kullanımı da görüşmecilerin çeşitli örnekler üzerinden açıklığa kavuşturdukları yeterlilikler olarak ön plana çıkmaktadır. $\mathrm{Bu}$ çerçevedeki benzer kullanıcı görüşleri aşağıdaki tek bir alıntıda verilmiştir.

İhtiyaç duyduğu hizmet ya da özellik için uygulama dükkanlarında arama yapabilir ve ihtiyacı olan uygulamayı cihazına yükleyebilir. Cihazlarını kişiselleștirebilir (örn. Arkaplan değiştirebilir, uygulamaların yerlerini değiştirebilir). Cep telefonu kullanımına ilişkin kalan kota (internet) ve dakika (konuşma) bilgilerini inceleyebilir. U1-U2-U5-U9

Bunların dıșında görüșmecilerin biri (U6), alan veya mesleği itibariyle dijital teknolojilere yakın olan ya da özel ilgisi olan dijital göçmenler haricinde ileri düzeyde kreatif kullanım ve dijital yeterlilik boşluklarının belirlenmesinin çok mümkün olmayabileceğini ifade etmiştir. U6'nın bu ifadesi diğer uzmanların ilgili hususlarda görüş belirtmemesi ile de örtüşmektedir.

\section{Literatür ve Sahanın Kesişiminde Dijital Yetkinlikleri Haritalamak}

$\mathrm{Bu}$ bölümde literatür ve sahanın kesişiminde, dijital göçmenler için bilgi-farkındalık, beceri ve tutumlara yönelen, temel ve orta düzeyde yeterliliklere odaklanan bir yetkinlik çerçevesinin geliştirilmesi amaçlanmaktadır. Elde edilen bulgular aşağıda sunulan tablolar halinde şekillenmiştir. 
Tablo 4. Ebeveynliğe İlişkin Dijital Yetkinlikler

\begin{tabular}{|c|c|c|}
\hline $\begin{array}{l}\text { Bir Sorumluluk ve } \\
\text { Sorun Alanı Olarak }\end{array}$ & Temel Yetkinlik Kategorileri & Dijital Göçmenler İçin Dijital Yetkinlikler \\
\hline \multirow{5}{*}{ EBEVEYNLIKK } & 1. Bilgi ve Veri Okuryazarlığı & $\begin{array}{l}\text { Veri, bilgi ve dijital içeriği tarama, filtreleme, değerlendirme, yönetme } \\
\text { - Arama motorlarını kullanarak ebeveynliğe } \\
\text { dair bilgi gereksinimini karşılayabilir. } \\
\text { - Arama motorlarının uzmanlık temelli ve nitelikli bilgiden } \\
\text { ziyade popüler içerikleri ön plana çıkardığının farkındadır. } \\
\text { - Arama sonucunda karşılaştığı içerikleri; kaynağı } \\
\text { (uzmanlık), yayıncısını (sitenin amacı, künyesi) } \\
\text { göz önünde bulundurarak değerlendirir. } \\
\text { - Dijital ortamlarda karşılaştığı içeriğe sağlıklı bir } \\
\text { şüphe ve eleştirel bir bakışla yaklaşabilir. }\end{array}$ \\
\hline & 2. İletişim ve İşbirliği & $\begin{array}{l}\text { Dijital teknolojiler aracılığılla etkileşim, paylaşım, vatandaşlığa } \\
\text { dahil olma, işbirliği, netiket ve dijital kımliği yönetme } \\
\text { - E-devlet, e-nabız gibi uygulamalar aracılığıyla } \\
\text { çocuğuyla ilgili resmi işlemleri yapabilir. } \\
\text { - Dijital nezaket kurallarının farkındadır. } \\
\text { Bunları çocuklarıyla da paylaşır. } \\
\text { - Çocuğun dijital ortamlarda kimliğini nasıl yönetmesi } \\
\text { gerektiği konusunda rehberlik yapabilir. Birlikte uygular. } \\
\text { • Çocukların, dijital ortamda yaptıkları herhangi } \\
\text { bir şeyin gerçek hayatta karşılığı olabileceği } \\
\text { konusunda onları bilinçlendirir. } \\
\text { - Çocuklarını, dijital ortamların hak temelli } \\
\text { kullanımı konusunda bilgilendirir. }\end{array}$ \\
\hline & 3. Dijital İçerik Oluşturma & $\begin{array}{l}\text { Dijital Içerik Geliştirme, Telif Hakkı ve Lisanslar } \\
\text { - Sosyal medya paylaşımlarının çocuklarının } \\
\text { mahremiyet ve unutulma haklarını ihlal edebileceğini ve } \\
\text { onların başkaları tarafından istismar edilmesine aracı } \\
\text { olabileceğini bilir ve paylaşımlarını buna göre düzenler. }\end{array}$ \\
\hline & 4. Güvenlik & $\begin{array}{l}\text { Cihazın, kişisel verilerin, gizliliğin, sağık ve esenliğin korunması } \\
\text { - Çocuğun gizliliğini ve kişisel verilerini tehlikeye atacak } \\
\text { tutum ve davranışları bilir ve bunlardan sakınır. } \\
\text { - Dijital oyunları, hakaret, siber zorbalık, kişisel veri } \\
\text { istismarı, dolandırılma, yalan haber ve bağımlıı gibi } \\
\text { risklerinin farkındadır. Bu konularda çocuklarını bilgilendirir. } \\
\text { - Güvenli internet hizmetinin farkındadır. Bu hizmet } \\
\text { aracılığıyla güvenli aile ve güvenli çocuk profilleri üretebilir. } \\
\text { - Çocukları zararlı içeriklerden korumak için } \\
\text { sosyal medya uygulamalarının ve arama } \\
\text { motorlarının reklam ayarlarını yönetebilir. } \\
\text { - Kendi çocuğunu ve gerektiğinde diğer çocukları } \\
\text { korumak için inbar web hizmetini kullanabilir. } \\
\text { - Sosyal medya platformlarının ve internet tarayıcılarının } \\
\text { sunduğu yaş sınırlaması ve ebeveyn kontrol panellerinden } \\
\text { yardım alarak da kontrol ve güven sağlayabilir. } \\
\text { - Çocuklarını parola güvenliği hakkında bilgilendirir. } \\
\text { - Çocukların cihaz kullanım bilgilerini } \\
\text { nasıl kontrol edebileceğini bilir. } \\
\text { - Ebeveyn denetimine olanak sağlayan } \\
\text { araç ve uygulamaları kullanır. } \\
\text { - Ağ bağlantılı oyuncakların güvenli kullanımını destekler. }\end{array}$ \\
\hline & 5. Problem Çözme & $\begin{array}{l}\text { Teknik sorunları çözme, ihtiyaçlara dönük kreatif kullanım } \\
\text { • Çocuklar için sosyal medya hesaplarını } \\
\text { kullanma sıklığına, ekranlara bakma sürelerine } \\
\text { ve çevrimiçi oyun oynama sürelerine ilişkin } \\
\text { ortak bir zaman yönetimi planı oluşturur. } \\
\text { • Sağlıklı cihaz kullanımını çocukları için modeller. } \\
\text { • Çocuğun gelişimi veya engelleri için ihtiyaç duyulan } \\
\text { hizmet ya da özellikler için uygulama mağazalarında arama } \\
\text { yapabilir ve ihtiyacı olan uygulamayı cihazına yükleyebilir. }\end{array}$ \\
\hline
\end{tabular}


Tablo 5. Mesleğe İlişkin Dijital Yetkinlikler ${ }^{1}$

\begin{tabular}{|c|c|c|}
\hline $\begin{array}{l}\text { Bir Sorumluluk ve } \\
\text { Sorun Alanı Olarak }\end{array}$ & Temel Yetkinlik Kategorileri & Dijital Göçmenler İçin Dijital Yetkinlikler \\
\hline \multirow{5}{*}{ MESLEK } & 1. Bilgi ve Veri Okuryazarlığı & $\begin{array}{l}\text { Veri, bilgi ve dijital içeriği tarama, filtreleme, değerlendirme, yönetme } \\
\text { - Arama motorları ve ilgili araçları kullanarak işe } \\
\text { yönelik verimli ve bağımsız arama gerçekleştirebilir. } \\
\text { - Ulaştığı dijital verileri kalite, uygunluk ve } \\
\text { güvenilirliğine göre değerlendirir. } \\
\text { - Dijital verileri mesleki ihtiyaçları çerçevesinde } \\
\text { yararlı, yapılandırılmış bir şekilde arşivleyip } \\
\text { düzenleyebilir. Bu çerçevede bulut teknolojilerini } \\
\text { senkronize bir biçimde kullanır. } \\
\text { - Dijital ortamlarda karşılaşığı içeriğe sağlıklı bir } \\
\text { şüphe ve eleştirel bir bakş̧la yaklaşabilir. }\end{array}$ \\
\hline & 2. İletişim ve İşbirliği & 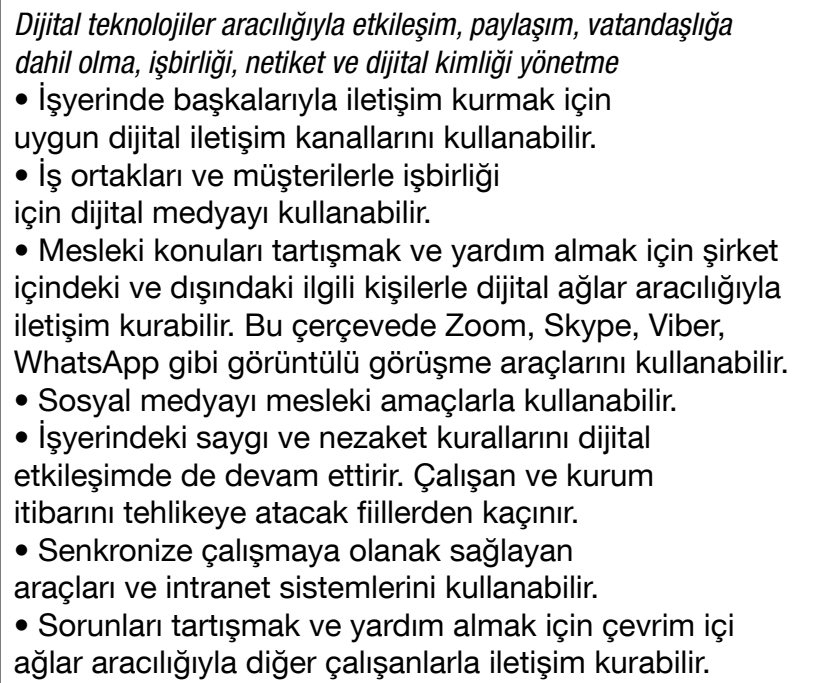 \\
\hline & 3. Dijital İçerik Oluşturma & $\begin{array}{l}\text { Dijital Içerik Geliştirme, Telif Hakkı ve Lisanslar } \\
\text { - Dijital ortamlardaki mesleki kaynakları kullanırken } \\
\text { telif haklarına ve lisanlamaya dikkat eder. } \\
\text { - Iss ile ilgili içerik gelisstirme araçlarıı (PowerPoint, } \\
\text { Excel, Word, Outlook) kullanır ve ilgili yazılımları bilir. }\end{array}$ \\
\hline & 4. Güvenlik & 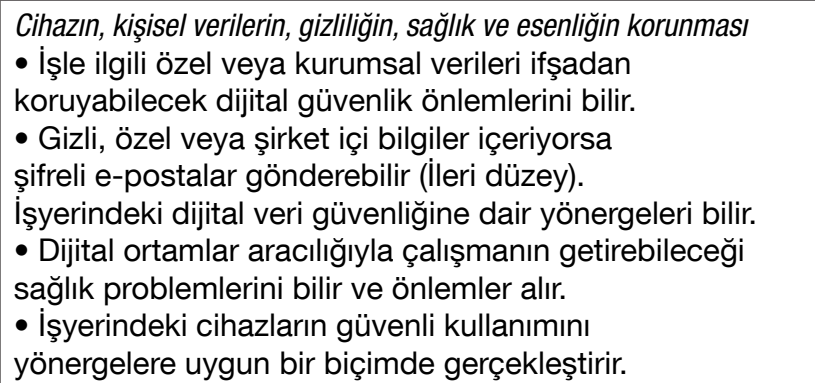 \\
\hline & 5. Problem Çözme & $\begin{array}{l}\text { Teknik sorunları çözme, ihtiyaçlara dönük kreatif kullanım } \\
\text { • İsyerindeki dijital faaliyetlerle ilgili sorunlarda } \\
\text { kurumsal yönerge ve talimatları gözden geçirir. } \\
\text { • Isş yaşamındaki dijital dönüšümü takip ederek, eğitim } \\
\text { ve bilgilenme gereksinimlerini karşıllamaya çalışır. } \\
\text { • Çalışma verimliliğini artırmak için dijital uygulamaların } \\
\text { ve medyanın potansiyelini bilir ve kullanır. } \\
\text { - Mesleki yaşantısına ilişsin yeni dijital } \\
\text { araçları kullanmayı dener. } \\
\text { - Işyerindeki cihazlarla ilgili teknik sorunlar yaşadığında } \\
\text { yönergeleri kullanarak basit çözümler üretebilir. }\end{array}$ \\
\hline
\end{tabular}


Tablo 6. Sağlık ve İyi Oluşa İlişskin Dijital Yetkinlikler

\begin{tabular}{|c|c|c|}
\hline $\begin{array}{l}\text { Bir Sorumluluk ve } \\
\text { Sorun Alanı Olarak }\end{array}$ & Temel Yetkinlik Kategorileri & Dijital Göçmenler İçin Dijital Yetkinlikler \\
\hline \multirow{5}{*}{$\begin{array}{l}\text { SAĞLIK VE } \\
\text { IYYI OLUŞ }\end{array}$} & 1. Bilgi ve Veri Okuryazarlığı & $\begin{array}{l}\text { Veri, bilgi ve dijital içeriği tarama, filtreleme, değerlendirme, yönetme } \\
\text { - Arama motorları ve online sağlık kaynakları } \\
\text { aracılığıyla yararlı sağlık bilgisine erişebilir. } \\
\text { - Ulaştığı sağlıkla ilgili verileri kalite, uygunluk } \\
\text { ve güvenilirliğine göre değerlendirebilir. } \\
\text { - Online ortamlardan edindiği bilgilerin kesin } \\
\text { tıbbi tanı için yeterli olmadığının farkındadır. } \\
\text { - Ağ ortamlarında (sosyal medya, forum siteleri vb.) } \\
\text { dolaşan sağlık bilgisinin güvenilirliğine şüphe ile yaklaşır. }\end{array}$ \\
\hline & 2. İletişim ve İşbirliği & $\begin{array}{l}\text { Dijital teknolojiler aracılığıyla etkileşim, paylaşım, vatandaşlığa } \\
\text { dahil olma, işbirliği, netiket ve dijital kimliği yönetme } \\
\text { - Uygun dijital iletişim kanalları aracılığıyla } \\
\text { bakım verenlerle irtibat kurabilir. } \\
\text { - Merkezi Hasta Randevu Sistemini (MHRS) } \\
\text { kullanarak doktor randevusu alabilir. } \\
\text { - E-Nabız aracılığıyla kişisel sağlık bilgilerini yönetebilir. } \\
\text { - Hayat Eve Sığar uygulamasından HES kodu üretebilir. } \\
\text { - Gerektiğinde HES kodunu kolayca paylaşabilir. } \\
\text { - Sosyal medya aracılığıyla aynı hastalığı } \\
\text { paylaşanlarla bağ kurabilir. Sağlık ve esenliğini } \\
\text { destekleyecek faaliyetlere katılabilir. }\end{array}$ \\
\hline & 3. Dijital İçerik Oluşturma & $\begin{array}{l}\text { Dijital Içerik Geliştirme, Telif Hakkı ve Lisanslar } \\
\text { - Sağlık cihazları ve sağlık uygulamaları } \\
\text { için gerekli dijital içeriği üretebilir. }\end{array}$ \\
\hline & 4. Güvenlik & $\begin{array}{l}\text { Cihazın, kişisel verilerin, gizliliğin, sağlık ve esenliğin korunması } \\
\text { - Tıbbi destek adı altındaki reklam ve tüketim } \\
\text { çabalarının farkında varır. Bu konuda pek } \\
\text { çok web sitesinin aktif olduğunu bilir. } \\
\text { • Çevrim içi enformasyonun denetimsiz dolaşımının } \\
\text { oluşturduğu yanlış bilgilenmenin sağlıkla ilgili bilgiler } \\
\text { konusunda bir karmaşaya ve kaygıya yol açacağını bilir. } \\
\text { - Sağlık bilgisi aradığı web sitesinin gizlilik politikasına } \\
\text { dikkat eder. Kişisel verilerinin korunduğundan emin olur. } \\
\text { - Sağlıkla ilgili mobil uygulamaların gizlilik } \\
\text { ayarlarını kontrol ve organize edebilir. } \\
\text { - Dijital ortamların bağımlılık, siber zorbalık, kişisel } \\
\text { veri istismarı, dolandırıma, yalan haber gibi psikolojik } \\
\text { esenliğe zarar verebilecek yönlerinin farkındadır. }\end{array}$ \\
\hline & 5. Problem Çözme & $\begin{array}{l}\text { Teknik sorunları çözme, ihtiyaçlara dönük kreatif kullanım } \\
\text { - Sağlığı geliştirmeye katkı sunabilecek mobil } \\
\text { uygulamaları indirip kullanabilir (kalori ve nabız ölçme, } \\
\text { ilaç takibi, adım sayma, fitness alıştırmaları vb.). } \\
\text { • Sağlıkla ilgili mobil uygulamaların ve dijital } \\
\text { teknolojilerin sunacağı kazanımların farkındadır. } \\
\text { • Bilgisayar ve internet kullanımının oluşturabileceği } \\
\text { fiziksel ve psikolojik sağlık sorunlarının } \\
\text { farkındadır ve bunlar için önlemler alır. }\end{array}$ \\
\hline
\end{tabular}


Tablo 7. Dijital Vatandaşlığa İlişkin Dijital Yetkinlikler

\begin{tabular}{|c|c|c|}
\hline $\begin{array}{l}\text { Bir Sorumluluk ve } \\
\text { Sorun Alanı Olarak }\end{array}$ & Temel Yetkinlik Kategorileri & Dijital Göçmenler İçin Dijital Yetkinlikler \\
\hline \multirow{5}{*}{$\begin{array}{l}\text { DiJITAL } \\
\text { VATANDAŞLIK }\end{array}$} & 1. Bilgi ve Veri Okuryazarlığı & $\begin{array}{l}\text { Veri, bilgi ve dijital içeriği tarama, filtreleme, değerlendirme, yönetme } \\
\text { - Arama motorları aracilığıyla kissisel ve mesleki } \\
\text { yeterliliklerinin gelişimini destekleyecek aramalar yapabilir. } \\
\text { - Kişisel ve mesleki yeterliliklerinin gelişimini } \\
\text { destekleyecek veriyi depolayıp yönetebilir. } \\
\text { - Topluma etkin katılımın temeli olarak dijital } \\
\text { içeriklere eleştirel bir bakış açısıyla yaklaşır. Haber, } \\
\text { bilgi doğrulama-teyit platformlarını kullanabilir. } \\
\text { - Dijital ortamlarda karşılaştı̆ı içeriğe sağlıklı bir } \\
\text { şüphe ve eleştirel bir bakışla yaklaşabilir. }\end{array}$ \\
\hline & 2. İletişim ve İşbirliği & $\begin{array}{l}\text { Dijital teknolojiler aracılığılla etkileşim, paylaşım, vatandaşl/ğa } \\
\text { dahil olma, işbirliği, netiket ve dijital kimliği yönetme } \\
\text { - Çevrim içi ortamlarda saygı ve } \\
\text { empati temelli iletişim kurar. } \\
\text { - Dijital araçları sosyal sorumluluk, toplumsal } \\
\text { sorunlara çözüm arayışları gibi aktif sivil } \\
\text { katılım amaçlarılyla kullanabilir. } \\
\text { - Dijital ortamların politik, ekonomik ve } \\
\text { kültürel katılım olanaklarının farkındadır. } \\
\text { - Online ortamları kişisel ve mesleki } \\
\text { yeterliliklerinin gelişimi için kullanabilir. } \\
\text { - Dijital ortamlardaki hak ve sorumluluklarının farkındadır. } \\
\text { - Ürün ve hizmetlere güvenli erişim, satın } \\
\text { alma ve tüketim yeterliliklerine sahiptir. } \\
\text { - E-devlet hizmetlerinden yararlanabilir. } \\
\text { Dijitalleşen kamu hizmetlerine entegre olabilir. } \\
\text { - Dijital bankacilık işlemlerini gerçekleştirebilir. }\end{array}$ \\
\hline & 3. Dijital İçerik Oluşturma & $\begin{array}{l}\text { Dijital Içerik Geliştirme, Telif Hakkı ve Lisanslar } \\
\text { - Dijital ortamlarda hedefe yönelik (meslek, sağlık, } \\
\text { hobiler vb.) doğru ve tutarlı yazill, görsel, işitsel } \\
\text { içerikler geliştirebilir ve içerikleri kaldırabilir. }\end{array}$ \\
\hline & 4. Güvenlik & $\begin{array}{l}\text { Cihazın, kişisel verilerin, gizliliğin, sağılı ve esenliğin korunması } \\
\text { - Çevrim içi ortamlarda kendisinin ve başkalarının } \\
\text { güvenlik ihtiyaçlarının farkındadır. } \\
\text { - Kendisi ve başkaları için güvenli alanlar oluşturabilir. } \\
\text { - Dijital ortamlardaki fikri mülkiyet ve } \\
\text { diğer haklara saygı duyar. } \\
\text { - Dijital ortamlarda kişisel sağlık ve esenliğini } \\
\text { etkileyecek zorluk ve fırsatların farkındadır. } \\
\text { - Dijital araçları kullanırken fiziksel, duygusal } \\
\text { ve zihinsel sağlığa önem verir. } \\
\text { - Dijital varlığını koruyacak önlemler alır. Ağ, } \\
\text { cihaz, veri ve izlerin güvenliğini yönetebilir. } \\
\text { - Online ortamlardaki suçları ve } \\
\text { mücadele yöntemlerini bilir. } \\
\text { - Kimlik numarası, anne kızlık soyadı, kredi kartı } \\
\text { numarası gibi hassas bilgilerin gizliliğine dikkat eder. }\end{array}$ \\
\hline & 5. Problem Çözme & $\begin{array}{l}\text { Teknik sorunları çözme, ihtiyaçlara dönük kreatif kullanım } \\
\text { - Dijitalleşen kamu hizmetleriyle ilgili sorunları } \\
\text { aşmak için yönerge ve talimatları kullanabilir. }\end{array}$ \\
\hline
\end{tabular}


Tablo 8. Hayat Boyu Öğrenmeye İlişkin Dijital Yetkinlikler

\begin{tabular}{|c|c|c|}
\hline $\begin{array}{l}\text { Bir Sorumluluk ve } \\
\text { Sorun Alanı Olarak }\end{array}$ & Temel Yetkinlik Kategorileri & Dijital Göçmenler İçin Dijital Yetkinlikler \\
\hline \multirow{5}{*}{$\begin{array}{l}\text { HAYAT BOYU } \\
\text { ÖĞRENME }\end{array}$} & 1. Bilgi ve Veri Okuryazarlığı & $\begin{array}{l}\text { Veri, bilgi ve dijital içeriği tarama, filtreleme, değerlendirme, yönetme } \\
\text { - Arama motorlarını kullanarak eğitim ve öğrenme } \\
\text { için gerekli veri, bilgi ve enformasyonu arayabilir. } \\
\text { • İnternet ortamlarındaki uzmanlaşmış akademik bilgi } \\
\text { ve enformasyon arama motorlarının farkındadır. } \\
\text { • Eğitim ve öğrenme süreçlerinde kullanacağı } \\
\text { kaynakları indirip depolayabilir. Bunun } \\
\text { için bulut teknolojilerini kullanabilir. } \\
\text { • Dijital ortamlarda karşılaştı̆̆ içeriğe sağlıklı bir } \\
\text { şüphe ve eleştirel bir bakışla yaklaşabilir. }\end{array}$ \\
\hline & 2. İletişim ve İşbirliği & $\begin{array}{l}\text { Dijital teknolojiler aracılığılla etkileşim, paylaşım, vatandaşlığa } \\
\text { dahil olma, işbirliği, netiket ve dijital kimliği yönetme } \\
\text { - Uzaktan senkronize öğrenme faaliyetlerinin } \\
\text { gerektirdiği temel teknik becerilere sahiptir } \\
\text { (kulaklık, mikrofon, kamera kullanımı vb.). } \\
\text { - Kurs vb. ücretli öğrenme etkinliklerine kayıt olabilir. } \\
\text { - Eğitim süreçlerini gerektirdiği etkileşimli mesajlaşma } \\
\text { ortamlarını kullanabilir (mail, mesajlaşma, online sınıf vb.). } \\
\text { • E-öğrenme araçlarında profil oluşturabilir. } \\
\text { - Güvenlik ve kişisel verilerin korunması için öğrenme } \\
\text { platformlarında güçlü parolalar belirleyebilir. } \\
\text { - E-öğrenme ortamlarında saygı ve } \\
\text { empati temelli iletişim kurar. }\end{array}$ \\
\hline & 3. Dijital İçerik Oluşturma & $\begin{array}{l}\text { Dijital Içerik Geliştirme, Telif Hakkı ve Lisanslar } \\
\text { - Online öğrenme kaynaklarının telif haklarına dikkat eder. } \\
\text { - Kurs vb. ücretli öğrenme etkinliklerine } \\
\text { online ödeme yaparak katılabilir. } \\
\text { - Word, PowerPoint, Excel ve benzer araçları } \\
\text { içerik üretmek ve paylaşmak için kullanabilir. }\end{array}$ \\
\hline & 4. Güvenlik & $\begin{array}{l}\text { Cihazın, kişisel verilerin, gizliliğin, sağlık ve esenliğin korunması } \\
\text { • Öğrenme ortamlarında dijital varlığını } \\
\text { koruyacak önlemler alır. Ağ, cihaz, veri } \\
\text { ve izlerin güvenliğini yönetebilir. } \\
\text { • Eğitim kaynaklarını güvenli olarak } \\
\text { depolayacağı araçları kullanabilir. }\end{array}$ \\
\hline & 5. Problem Çözme & $\begin{array}{l}\text { Teknik sorunları çözme, ihtiyaçlara dönük kreatif kullanım } \\
\text { - Dijital ortamlarının sunduğu öğrenme fırsatlarını kişisel } \\
\text { ve mesleki gelişimi için kullanabileceğinin farkındadır. } \\
\text { • Dijital teknolojileri kendi öğrenme biçimini } \\
\text { destekleyecek şekilde kullanır. } \\
\text { • Eğitimi destekleyecek mobil uygulamaların ve dijital } \\
\text { teknolojilerin sunacağı kazanımların farkındadır. } \\
\text { - Eğitime katkı sunabilecek mobil } \\
\text { uygulamaları indirip kullanabilir. } \\
\text { - Özel eğitim intiyacına yönelik eğitim fırsatlarına erişebilir. }\end{array}$ \\
\hline
\end{tabular}


Tablo 9. İletişim-Etkileșim, Eğlenme-Sosyalleșmeye Illişkin Dijital Yetkinlikler

\begin{tabular}{|c|c|c|}
\hline $\begin{array}{l}\text { Bir Sorumluluk ve } \\
\text { Sorun Alanı Olarak }\end{array}$ & Temel Yetkinlik Kategorileri & Dijital Göçmenler İçin Dijital Yetkinlikler \\
\hline \multirow{5}{*}{$\begin{array}{l}\text { ILETIŞIM- } \\
\text { ETKILEŞiM VE } \\
\text { EĞLENME- } \\
\text { SOSYALLEŞME }\end{array}$} & 1. Bilgi ve Veri Okuryazarlığı & $\begin{array}{l}\text { Veri, bilgi ve dijital içeriği tarama, filtreleme, değerlendirme, yönetme } \\
\text { - Arama motorlarını kullanarak eğlenme ve } \\
\text { sosyalleşme amaçlı içerik ve uygulamaları arayabilir. } \\
\text { • Eriştiği içeriklerin gerçekliğine ve doğruluğuna eleştirel } \\
\text { bir gözle bakıp, sorgulayabilme becerisine sahiptir. } \\
\text { Gerektiğinde doğrulama platformlarını kullanabilir. } \\
\text { - Eriştiği eğlenme ve sosyalleşme amaçlı içerik } \\
\text { ve uygulamaları indirerek farlı zamanlarda } \\
\text { internet bağlantısı olmaksızın kullanabilir. }\end{array}$ \\
\hline & 2. İletişim ve İşbirliği & $\begin{array}{l}\text { Dijital teknolojiler aracılığıyla etkileşim, paylaşım, vatandaşlığa } \\
\text { dâhil olma, işbirliği, netiket ve dijital kimliği yönetme } \\
\text { - Aile, yakınlar ve sosyal çevre ile iletişim } \\
\text { kurmak için mesajlaşma ve görüntülü } \\
\text { konuşma uygulamalarını kullanabilir. } \\
\text { - Sosyal medya hesaplarında profil oluşturabilir. } \\
\text { - Sosyal medya hesapları aracılığıyla } \\
\text { mesaj gönderip alabilir. } \\
\text { - Sosyal medya platformlarında ilgi duyduğu hesapları } \\
\text { takip edebilir ve gerekli gördüğünde takipten çıkabilir. } \\
\text { - Dijital görgü kurallarına dikkat eder. } \\
\text { - Dijital ortamların eğlenme ve sosyalleşme } \\
\text { için sunduğu imkânların farkındadır. } \\
\text { - Etkileşimli oyun ve eğlenme uygulamalarında profil } \\
\text { oluşturabilir ve diğer oyuncularla etkileşim kurabilir. } \\
\text { - Telefon rehberine numara kaydedebilir, güncelleyebilir, } \\
\text { numarayı paylaşabilir, rehberde arama yapabilir. }\end{array}$ \\
\hline & 3. Dijital İçerik Oluşturma & $\begin{array}{l}\text { Dijital İçerik Geliştirme, Telif Hakkı ve Lisanslar } \\
\text { - Telefon ile fotoğraf, video veya ses kaydedip } \\
\text { kaydettiği içerikleri yakınlarıyla paylaşabilir. } \\
\text { - Ürettiği içerikleri sosyal medya } \\
\text { platformlarında paylaşabilir. } \\
\text { - Yasadışı içerikleri indirmekten, paylaşmaktan } \\
\text { veya saklamaktan kaçınır. } \\
\text { - Telif hakkı olan materyalleri indirmez sahibi } \\
\text { olmadığı eserleri topluluklarla paylaşmaz. }\end{array}$ \\
\hline & 4. Güvenlik & $\begin{array}{l}\text { Cihazın, kişisel verilerin, gizliliğin, sağıı ve esenliğin korunması } \\
\text { - Gizliliğini ve kişisel verilerini tehlikeye atacak } \\
\text { tutum ve davranışları bilir ve bunlardan sakınır. } \\
\text { • Oyun ve eğlenme platformlarındaki hakaret, siber } \\
\text { zorbalık, kişisel veri istismarı, dolandırılma, yalan } \\
\text { haber ve bağımlılık gibi risklerinin farkındadır. } \\
\text { - Sosyal medya uygulamalarının ve arama } \\
\text { motorlarının reklam ayarlarını yönetebilir. } \\
\text { - Oyun ve uygulama reklamlarının dolandıııma, } \\
\text { oltalama amaçlı kullanılabildiğinin farkındadır. } \\
\text { - Kullandığı sosyal ağ platformlarının güvenlik ve gizlilik } \\
\text { ayarlarını kontrol edebilir ve düzenleme yapabilir. } \\
\text { - Sosyal medya platformlarında parola güvenliğine } \\
\text { dikkat eder. Güçclü parolalar oluşturur. } \\
\text { - Sosyal ağlar ve web servislerinin } 3 \text {. } \\
\text { Parti uygulamalarını engelleyebilir. }\end{array}$ \\
\hline & 5. Problem Çözme & $\begin{array}{l}\text { Teknik sorunları çözme, ihtiyaçlara dönük kreatif kullanım } \\
\text { - Dijital ortamların bağımsız olma, yalnızlığın sıkıntısını } \\
\text { hafifletme ve sosyalleşme için bir imkân olduğunu bilir. } \\
\text { • Eğlenme ve sosyalleşme amacıyla intiyaç duyulan } \\
\text { hizmet ya da özellikler için uygulama dükkanlarında arama } \\
\text { yapabilir ve ihtiyacı olan uygulamayı cihazına yükleyebilir. } \\
\text { - Mobil mağazalardan indireceği uygulamaların kullanıcı } \\
\text { yorumlarını okuyarak potansiyel sorunları engelleyebilir. }\end{array}$ \\
\hline
\end{tabular}




\section{Sonuç}

Dijital çağda yetişkin eğitimi, hayat boyu öğrenme politikalarının önemli bir parçası haline gelmiştir. Dijital yeterlilikler de hayat boyu öğrenme için temel yeterliliklerin başında gelmektedir. Zira bilgi ve iletişim teknolojilerinin yaygınlaşması, toplumu bir ağ toplumuna dönüştürmüştür; ancak bu yeni toplum modelinde eşitsizliklerin, kullanım becerileri üzerinden devam ettiği görülmektedir. Kullanım becerilerinden kaynaklı bölünmenin artan yașa ve yaşla ilişkili faktörlere bağlı olarak derinleștiği ise literatürde neredeyse fikir birliğine varılan bir noktadır. Dijital teknolojilerin sağlıklı bir yaşlanma için sunduğu firsatların kaçırılmasıyla birlikte beraberinde getirdiği riskleri de belirginleștiren söz konusu bölünme ciddi bir sorun alanı oluşturmakta; dijital teknolojilerin benimsenmesine ilişkin kapasite geliştirme çabalarını önemli bir gereklilik olarak işaretlemektedir.

Bu çerçevede ilkin dijital bölünmede yaş faktörünün etkisi sorunsallaştırılmış, ardından yaşa bağlı dijital bölünmenin çeşitli yansımalarıyla karşı karşıya gelen ve kendi içerisinde çeşitlilik arz eden dijital göçmenlerin, dijital teknolojilerle ilgili hangi sorumluluk ve sorun alanlarıyla karşı karşıya oldukları literatür incelemesiyle ortaya konmuştur. Hemen ardından literatürdeki kapsamlı bir genel yetkinlik çerçevesine referansla dijital göçmenlerin söz konusu sorumluluk ve sorun alanlarındaki yetkinliklerinin hangi kategorilerde ele alınabileceği ortaya konmuştur. Saha kısmında ise ilgili literatürden elde edilen veriler çerçevesinde uzman görüşlerine yer verilmiştir. Son olarak da tüm bu hasıladan hareketle dijital göçmenler için bilgi-farkındalık, beceri ve tutumlara yönelen, temel ve orta düzeyde yeterliliklere odaklanan bir yetkinlik çerçevesi geliştirilmiştir.

Söz konusu çerçeve özgün bir kurguya sahip olması bakımından önem arz etmekte ve gelecek çalışmalar için bir başlangıç noktasını işaretlemektedir. Eksiksiz olmadığı gibi yeni akademik tartışmalarla eleştirilmeye ve geliştirilmeye muhtaçtır. Aynı zamanda bu türden bir yetkinlik çerçevesi, dijital göçmenlerin dijital yeterliliklerini geliştirmeleri için tek başına yeterli görünmemektedir. Bireysel bilgi, farkındalık, beceri ve tutumlarla birlikte düzenleyici ve koruyucu kurumların da rolü ve önemi ayrıca ifade edilmelidir.

\section{Notlar}

1 Mesleğe ilişkin yetkinlik çerçevesinin geliştirilmesinde literatür ve saha verilerinin yanında büyük oranda "Digital competencies: A review of the literature and applications in the workplace (Oberländer vd., 2020)" isimli araştırmadan faydalanılmıştır.

\section{Kaynakça}

Akhter, S. H. (2003). Digital divide and purchase intention: Why demographic psychology matters. Journal of Economic Psychology, 24(3), 321-327. https://doi. org/10.1016/S0167-4870(02)00171-X

Ala-Mutka, K. (2011). Mapping digital competence: Towards a conceptual understanding. https://www.researchgate.net/publication/340375234_Mapping_Digital_ Competence_Towards_a_Conceptual_Understanding

Aldemir, C., \& Avşar, M. N. (2020). Pandemi döneminde dijital vatandaşlık uygulamaları. Avrasya Sosyal ve Ekonomi Araştırmaları Dergisi, 7(5), 148-169.

Ambert, A.-M. (2001). The effect of children on parents. Psychology Press. 
Amundsen, D. (2021). Digital technologies as a panacea for social isolation and loneliness among older adults: An intervention model for flourishing and wellbeing: Visual technologies as a panacea for social isolation. Video Journal of Education and Pedagogy, 5(1), 1-14. https://doi.org/10.1163/2364458300501008

Baecker, R., Sellen, K., Crosskey, S., Boscart, V., \& Neves, B. (2014). Technology to reduce social isolation and loneliness. ASSETS '14, ACM SIGACCESS Computers \& accessibility. https://doi.org/10.1145/2661334.2661375

Baez, M., Nielek, R., Casati, F., \& Wierzbicki, A. (2019). Technologies for promoting social participation in later life. İçinde B. B. Neves \& F. Vetere (Ed.), Ageing and Digital Technology: Designing and Evaluating Emerging Technologies for Older Adults (ss. 285-306). Springer Singapore. https://doi.org/10.1007/978-981-13-3693-5_17

Bayne, S., \& Ross, J. (2007). The "digital native" and "digital immigrant": A dangerous opposition.

Blum-Ross, A., \& Livingstone, S. (2017). “Sharenting," parent blogging, and the boundaries of the digital self. Popular Communication, 15(2), 110-125. https:// doi.org/10.1080/15405702.2016.1223300

Brown, I., \& Licker, P. (2003). Exploring differences in internet adoption and usage between historically advantaged and disadvantaged groups in South Africa. Journal of Global Information Technology Management, 6(4), 6-26. https://doi.org/ 10.1080/1097198X.2003.10856358

Büyüköztürk, Ş. (2012). Örnekleme yöntemleri. http://cv.ankara.edu.tr/duzenleme/ kisisel/dosyalar/21082015162828.pdf

Carretero, S., Vuorikari, R., Punie, Y., European Commission, \& Joint Research Centre. (2017). DigComp 2.1 the digital competence framework for citizens with eight proficiency levels and examples of use.

Chakraborty, J., \& Bosman, M. M. (2002). Race, income, and home PC ownership: A regional analysis of the digital divide. Race and Society, 5(2), 163-177. https://doi. org/10.1016/j.racsoc.2004.01.003

Chalklen, C., \& Anderson, H. (2017). Mothering on Facebook: Exploring the privacy/ openness paradox. Social Media + Society, 3(2), 2056305117707187. https://doi. org/10.1177/2056305117707187

Chaudhuri, A., Flamm, K. S., \& Horrigan, J. (2005). An analysis of the determinants of internet access. A selection of papers from the 32nd Annual Telecommunications Policy Research Conference, 29(9), 731-755. https://doi.org/10.1016/j. telpol.2005.07.001

Choi, M. (2016). A concept analysis of digital citizenship for democratic citizenship education in the internet age. Theory \& Research in Social Education, 44(4), 565607. https://doi.org/10.1080/00933104.2016.1210549

Chopik, W. J. (2016). The benefits of social technology use among older adults are mediated by reduced loneliness. Cyberpsychology, Behavior and Social Networking, 19(9), 551-556. PubMed. https://doi.org/10.1089/cyber.2016.0151 
Cotten, S. R., Ford, G., Ford, S., \& Hale, T. M. (2014). Internet use and depression among retired older adults in the United States: A Longitudinal Analysis. The Journals of Gerontology: Series B, 69(5), 763-771. https://doi.org/10.1093/geronb/gbu018

Council of Europe. (2021). Digital citizenship and digital citizenship education. Digital Citizenship Education (DCE). https://www.coe.int/en/web/digital-citizenshipeducation/digital-citizenship-and-digital-citizenship-education

Creswell, J. W. (2018). Nitel araştırma yöntemleri: Beş yaklaşıma göre nitel araştırma ve araştırma deseni (M. Bütün \& S. B. Demir, Çev.). Siyasal Kitabevi.

Cruz-Jesus, F., Vicente, M. R., Bacao, F., \& Oliveira, T. (2016). The education-related digital divide: An analysis for the EU-28. Computers in Human Behavior, 56, 72-82. https://doi.org/10.1016/j.chb.2015.11.027

Curtis, K., \& Price, K. (2017). Factors that influence older people's engagement with digital health technology. Nursing older people, 29 10, 27-30.

Çimke, S., Gürkan, D. Y., \& Polat, S. (2018). Sosyal medyada çocuk hakki ihlali: Sharenting. Güncel Pediatri, 16(2), 261-267.

Eken, M. (2021). Pandemi sürecinde işlevsel bir araç olarak internet: Görünüş ile gerçeklik arasında etkileşimli yaşam deneyimi. İçinde Rutin ve Hayret: Bir İmkan ve Imtihan Olarak Pandemi. DBY Yayınları.

Elena-Bucea, A., Cruz-Jesus, F., Oliveira, T., \& Coelho, P. S. (2020). Assessing the role of age, education, gender and income on the digital divide: Evidence for the European Union. Information Systems Frontiers. https://doi.org/10.1007/s10796020-10012-9

Eurostat. (2019). Individuals' level of digital skills. https://ec.europa.eu/eurostat/data/ database

Figan, M., \& Dede Özdemir, Y. (2020). Giriş. İçinde Dijital kültür, dijital eşitsizlikler ve yaşlanma (ss. 1-7). Alternatif Bilişim. https://ekitap.alternatifbilisim.org/pdf/ dijital_kultur_dijital_esitsizlikler_ve_yaslanma.pdf

Gao, Q., Prina, A., Prince, M., Acosta, D., Sosa, A. L., Guerra, M., Huang, Y., JimenezVelazquez, I., Rodriguez, J. L. L., Salas, A., Williams, J. D., Liu, Z., Castillo, I. A., \& Mayston, R. (2021). Loneliness among older adults in Latin America, China, and India: Prevalence, correlates and association with mortality. International Journal of Public Health.

Gorard, S., Furlong, J., \& Madden, L. (2003). Older adults' use of information and communication technology in everyday life. Ageing and Society, 23, 561-582. https://doi.org/10.1017/S0144686X03001302

Hargittai, E. (2020). İkinci seviye dijital bölünme: Bireylerin çevrimiçi becerilerindeki farklılıklar. İçinde Dijital kültür, dijital eşitsizlikler ve yaşlanma (ss. 25-48). Alternatif Bilişim. https://ekitap.alternatifbilisim.org/pdf/dijital_kultur_dijital_ esitsizlikler_ve_yaslanma.pdf

https://ec.europa.eu/. (t.y.). Glossary: Lifelong learning. Geliş tarihi 02 Temmuz 2021, gönderen https://ec.europa.eu/eurostat/statistics-explained/index. php?title=Glossary:Lifelong_learning 
Hubregtse, S. (2005). The digital divide within the European Union. New Library World, 106(3/4), 164-172. https://doi.org/10.1108/03074800510587363

Ijsselsteijn, W., Nap, H. H., Poels, K., \& De Kort, Y. (2007). Digital game design for elderly users. İçinde Proceedings of the 2007 Conference on Future Play, Future Play '07. https://doi.org/10.1145/1328202.1328206

Ivan, L., \& Fernández-Ardèvol, M. (2017). Older people and the use of ICTs to communicate with children and grandchildren. Transnational Social Review, 7(1), 41-55. https://doi.org/10.1080/21931674.2016.1277861

K Chen. (2020). Use of gerontology to assist older adults to cope with the Covid-19 pandemic. Journal of the American Medical Directors Association, 21(7), 983-984.

Karavidas, M., Lim, N. K., \& Katsikas, S. L. (2005). The effects of computers on older adult users. Computers in Human Behavior, 21(5), 697-711. https://doi.org/10.1016/j. chb.2004.03.012

Kirby, B., Birch, J.-L., Cain, J., \& Newland, V. (2017). Digital well-being across the agesgenerational perceptions of well-being in reference to the use of the internet and digital technology. https://publications.ergonomics.org.uk/uploads/Digital-WellBeing-Across-the-Ages-Generational-Perceptions-of-Well-Being-in-Reference-tothe-Use-of-the-Internet-and-Digital-Technology.pdf

Klimaszewski, C., \& Nyce, J. M. (2009). Does universal access mean equitable access? New Library World, 110(5/6), 219-236. https://doi. org/10.1108/03074800910954253

Kumar, P., \& Schoenebeck, S. (2015). The modern day baby book: Enacting good mothering and stewarding privacy on Facebook. Proceedings of the 18th ACM Conference on Computer Supported Cooperative Work \&amp; Social Computing, 1302-1312. https://doi.org/10.1145/2675133.2675149

Lee, C. C., Czaja, S. J., \& Sharit, J. (2009). Training older workers for technology-based employment. Educational Gerontology, 35(1), 15-31. PubMed. https://doi. org/10.1080/03601270802300091

Livingstone, S., \& Byrne, J. (2018). Parenting in the digital age. The challenges of parental responsibility in comparative perspective. İçinde Digital Parenting. The Challenges for Families in the Digital Age (ss. 19-30). Nordicom. https://www.nordicom. gu.se/sv/system/tdf/publikationer-hela-pdf/yearbook_2018_digital_parenting. pdf?file $=1 \&$ type $=$ node $\&$ id $=39884 \&$ force $=0$

Maftei, A., \& Holman, A. C. (2020). Cyberchondria during the coronavirus pandemic: The effects of neuroticism and optimism. Frontiers in Psychology, 11, 567345-567345. PubMed. https://doi.org/10.3389/fpsyg.2020.567345

Mossberger, K., Tolbert, C. J., \& McNeal, R. S. (2008). Digital citizenship: The internet, society, and participation. MIT Press.

Nelissen, S., \& Van den Bulck, J. (2018). When digital natives instruct digital immigrants: Active guidance of parental media use by children and conflict in the family. Information, Communication \& Society, 21(3), 375-387. https://doi.org/10.1080/1 369118X.2017.1281993 
Noh, Y.-H., \& Yoo, K. (2008). Internet, inequality and growth. Journal of Policy Modeling, 30(6), 1005-1016. https://doi.org/10.1016/j.jpolmod.2007.06.016

Oberländer, M., Beinicke, A., \& Bipp, T. (2020). Digital competencies: A review of the literature and applications in the workplace. Computers \& Education, 146, 103752. https://doi.org/10.1016/j.compedu.2019.103752

OECD. (2001). Understanding the digital divide (OECD Digital Economy Papers Sy 49; OECD Digital Economy Papers, C. 49). https://doi.org/10.1787/236405667766

OECD. (2003). Beyond rhetoric: Adult learning policies and practices. OECD. https://doi. org/10.1787/9789264199446-en

OECD. (2019). Working better with age. OECD. https://doi.org/10.1787/c4d4f66a-en

Özkan, S., Baran Aksakal, F. N., Çalışkan, D., Dikmen, A. U., \& Tüzün, H. (2018). Türkiye sağlık okuryazarlığı düzeyi ve ilişkili faktörleri araștırması. T.C. Sağlık Bakanlığı.

Özsoy, D. (2020). Dijital bölünme düzeylerine dair literatür analizi. İçinde Dijital kültür, dijital eşitsizlikler ve yaşlanma (ss. 11-23). Alternatif Bilişim. https://ekitap. alternatifbilisim.org/pdf/dijital_kultur_dijital_esitsizlikler_ve_yaslanma.pdf

Pieri, M., \& Diamantinir, D. (2010). Young people, elderly and ICT. Innovation and Creativity in Education, 2(2), 2422-2426. https://doi.org/10.1016/j. sbspro.2010.03.348

Pouster, J. (2016). Smartphone ownership and internet usage continues to climb in emerging economies. Pew Research Center. https://www.pewresearch.org/ global/2016/02/22/smartphone-ownership-and-internet-usage-continues-toclimb-in-emerging-economies/

Prensky, M. (2001a). Digital natives, digital immigrants part 1. On the Horizon, 9(5), 1-6. https://doi.org/10.1108/10748120110424816

Prensky, M. (2001b). Digital natives, digital immigrants part 2: Do they really think differently? On the Horizon, 9(6), 1-6. https://doi. org/10.1108/10748120110424843

Samek Lodovici, M., \& vd. (2021). The impact of teleworking and digital work on workers and society. European Parliament. https://www.europarl.europa.eu/RegData/ etudes/STUD/2021/662904/IPOL_STU(2021)662904_EN.pdf

Scheuermann, L., \& Taylor. (1997). Netiquette. Internet Research, 7(4), 269-273. https:// doi.org/10.1108/10662249710187268

Shirazi, F., Ngwenyama, O., \& Morawczynski, O. (2010). ICT expansion and the digital divide in democratic freedoms: An analysis of the impact of ICT expansion, education and ICT filtering on democracy. Telematics and Informatics, 27(1), 2131. https://doi.org/10.1016/j.tele.2009.05.001

Srinuan, C., \& Bohlin, E. (2011). Understanding the digital divide: A literature survey and ways forward. 22nd European Regional Conference of the International Telecommunications Society (ITS2011), Budapest, 18 - 21 September, 2011: Innovative ICTApplications - Emerging Regulatory, Economic and Policy Issues. 
Sütlüoğlu, T. (2020). Orta yaş ve üzerindeki bireylerde dijital eşitsizliğin görünümleri: Erişim eşitsizlikleri ve kullanım farklılıkları. İçinde Dijital kültür, Dijital eşitsizlikler ve yaşlanma (ss. 215-246). Alternatif Bilişim. https://ekitap.alternatifbilisim.org/ pdf/dijital_kultur_dijital_esitsizlikler_ve_yaslanma.pdf

The HLS-EU Consortium. (2012). The European Health Literacy Project (HLSEU), Executive summary (D17), Final Report. http://cpme.dyndns.org:591/ adopted/2015/Info.2015-095.Final_report_Executive_summary_of_HLS-EU.pdf

TÜİK. (2020). Son üç ay içinde bireylerin yaş grubuna ve cinsiyetine göre bilgisayar ve internet kullanım oranı, 2004-2020 (TÜIK'in hanehalkı bilişim teknolojileri (BT) kullanım araştırması). https://data.tuik.gov.tr/Bulten/Index?p=HanehalkiBilisim-Teknolojileri-(BT)-Kullanim-Arastirmasi-2020-33679

Van Dijk, J. (2016). Ağ toplumu (Ö. Sakin, Çev.). Kafka, Epsilon Yayıncılık.

van Dijk, J. A. G. M., \& van Deursen, A. J. A. M. (2014). Digital skills. Palgrave Macmillan US. https://doi.org/10.1057/9781137437037

Vartanova, E., \& Gladkova, A. (2019). New forms of the digital divide. İçinde Digital media inequalities: Policies against divides, distrust and discrimination (ss. 193-213). Nordicom.

von Doetinchem, S., \& Livingston, L. (2021). Lifelong learning in the age of COVID-19. http://generations.asaging.org/lifelong-learning-age-covid-19

Waycott, J., Bennett, S., Kennedy, G., Dalgarno, B., \& Gray, K. (2010). Digital divides? Student and staff perceptions of information and communication technologies. Computers \& Education, 54(4), 1202-1211. https://doi.org/10.1016/j. compedu.2009.11.006

Wilbon, A. D. (2003). Shrinking the digital divide: The moderating role of technology environments. Technology in Society, 25(1), 83-97. https://doi.org/10.1016/ S0160-791X(02)00063-5

Yang, K., \& Victor, C. (2011). Age and loneliness in 25 European nations. Ageing and Society, 31(8), 1368-1388. Cambridge Core. https://doi.org/10.1017/ S0144686X1000139X

Yurdakul, İ. K., Dönmez, O., Yaman, F., \& Odabaşi, H. F. (2013). Digital parenting and changing roles. Gaziantep University Journal of Social Sciences, 12(4), 883-896.

Zarcadoolas, C., Pleasant, A., \& Greer, D. (2005). Understanding health literacy: An expanded model. Health promotion international, 20, 195-203. https://doi. org/10.1093/heapro/dah609

Zhang, F., \& Kaufman, D. (2015). The impacts of social interactions in MMORPGs on older adults' social capital. Comput. Hum. Behav., 51(PA), 495-503. https://doi. org/10.1016/j.chb.2015.05.034

Zhao, H., Kim, S., Suh, T., \& Du, J. (2007). Social institutional explanations of global internet diffusion: A cross-country analysis. Journal of Global Information Management, 15(2), 28-55. Scopus. https://doi.org/10.4018/jgim.2007040102 


\title{
Digital Competencies for Digital Immigrants at the Intersection of Literature and the Field
}

\author{
Metin Eken (Asst. Prof. Dr.)
}

\section{Extended Abstract}

This study focuses on digital competencies for digital immigrants and was prepared within the scope of the project entitled "Improving Digital Competencies for Digital Immigrants: Tackling with Digital Divide and Digital Social Inequality", abbreviated to DigiComp, which was funded as part of the Erasmus+ Program School Education Strategic Partnerships action carried out by the Turkish National Agency.

Adult education has become an important component of lifelong learning policies in the digital age. Digital competencies have become one of the fundamental competencies for lifelong learning. Because of the proliferation of information and communication technologies, society has been transformed into a network society; however, inequalities in competencies persist in this new model. The fact that the divide due to competencies deepens with increasing age and age-related factors is a point on which a consensus has been reached in the literature. This division, which emphasizes the risks that digital technologies bring as well as missed opportunities for healthy aging, becomes concrete as an area of serious issue, and this makes capacity-building efforts on digital technology adoption an important requirement.

The study addresses this issue and aims to present a competency framework initiative based on differences and consensus by presenting a clearer picture of the digital competencies that digital immigrants should possess, within the framework of a literature review and expert opinions, in order to contribute to the academic ground of capacity building efforts related to digital technology adoption. Thus, this study aims to address the following questions:

1. What are the responsibilities and issues that digital immigrants face in terms of digital technologies?

2. What are the competency categories for digital immigrants related to the areas of responsibility and issues regarding digital technologies?

3. What competencies should digital immigrants possess in the competency categories for the areas of responsibility and issues they face with digital technologies?

The first two of these questions were specifically designed to be answered through a review of the literature. Expert interview-based field research was then conducted to both arbitrate the first two questions as well as reveal a general framework for the third. The study is significant because it focuses on digital immigrants, who are disadvantaged members of the digital divide, which has increasingly become one of the central agendas of policy development processes related to the adoption of information and communication technologies worldwide, and it differs from related studies in the literature in terms of its design and output.

In this framework, first, the effect of the age factor in the digital divide was problematized, and then, the areas of responsibility and issues of digital immigrants, who confront various reflections of the age-related digital divide and are diverse within themselves, 
were revealed by the literature review. Discussing the responsibilities and issues that digital immigrants face regarding digital technologies is also essential in terms of prioritizing which competencies are required in these areas. In this regard, when the extensive literature on the subject was examined, areas such as parenting, profession, health and well-being, digital citizenship, lifelong learning, communication-interaction, entertainment-socialization stood out as areas of responsibility and problem solving, particularly for digital immigrants. Rather than claiming to cover all areas of responsibility and issue, this classification aims to provide a framework for some major lines. Yet these issues, each of which can be evaluated within the scope of a separate study, have been discussed within the framework of study limitations, based on opportunities and risks, with general explanations and limited examples.

It was immediately clarified in which categories the competencies of digital immigrants in these areas of responsibility and issues could be considered. The European Digital Competence Framework for Citizens (version 2.1), abbreviated DigComp, the accepted framework put forward by the European Commission for digital competencies, was used as a reference in determining the digital competency categories in this framework.

In terms of field, expert opinions were provided within the context of data obtained from the relevant literature. In the process of determining the working group, the "criteria sampling method", one of the purposive sampling methods, was used. The creation of a sample from people, events, objects, or situations that have the characteristics determined for the problem is referred to as criterion sampling (Büyüköztürk, 2012). In this context, the views of eleven Turkish experts who had completed academic studies in the fields of digitalization and digital culture were sought. The identified experts are regarded as critical in terms of both their knowledge of the literature and the achievement of the research objectives related to focus observations and research on digital immigrants.

Finally, based on all of these results, a competency framework for digital immigrants was developed, focusing on knowledge-awareness, skills, and attitudes, as well as basic and intermediate competencies. The framework in question is significant since it has a distinct construct and serves as a starting point for future studies. As it is not complete, it is also in need of development with further academic discussion. In the meantime, such a competency framework alone is not sufficient to help digital immigrants develop their digital competencies. Along with individual knowledge, awareness, abilities, and attitudes, the role and significance of regulatory and protective institutions should be articulated.

Keywords: Digital Divide, Digital Inequality, Digital Immigrants, DigiComp, Digital Competencies. 
Bu makale intihal tespit yazııımlarıyla taranmışır. İtihal tespit edilmemiştir.

This article has been scanned by plagiarism detection softwares. No plagiarism detected.

Bu çalışmada "Yükseköğretim Kurumları Bilimsel Araştırma ve Yayın Etiği Yönergesi” kapsamında uyulması belirtilen kurallara uyulmuştur.

In this study, the rules stated in the "Higher Education Institutions Scientific Research and Publication Ethics Directive" were followed.

Araştırma tek bir yazar tarafından yürütülmüştür.

The research was conducted by a single author.

\section{Çıkar iliş̧kisi I Conflict of Interest}

Bu çalışma, DigiComp kısa adı ve "Dijital Göçmenler için Dijital Yeterlilikleri Artırma: Dijital Bölünme ve Dijital Sosyal Eşitsizlikle Mücadele" başlığılla Türkiye Ulusal Ajansı tarafından yürütülmekte olan Erasmus+ Programı Okul Eğitimi Stratejik Ortaklıklar eylemi kapsamında hibe almakta ve desteklenmektedir.

This study was prepared within the scope of the project entitled "Improving Digital Competencies for Digital Immigrants: Tackling with Digital Divide and Digital Social Inequality", abbreviated to DigiComp, which was funded as part of the Erasmus+ Program School Education Strategic Partnerships action carried out by the Turkish National Agency.

\section{Etik Kurul İzni I Ethics Committee Permission}

Bu çalışma, Erciyes Üniversitesi Sosyal ve Beşeri Bilimler Etik Kurulu tarafından, 29/06/2021 tarihli ve 284 başvuru numaralı onay formu ile etik açıdan uygun bulunmuştur.

Within the framework of the decision taken during the meeting by Erciyes University Social and Human Sciences Scientific Research and Publication Ethics Committee dated 29/06/2021 and numbered 284; the study does not contain any ethical issues. 